University of Nebraska - Lincoln

DigitalCommons@University of Nebraska - Lincoln

\title{
Effects of Calcium Magnesium Carbonate and Roughage Level on Feedlot Performance, Ruminal Metabolism, and Site and Extent of Digestion in Steers Fed High-Grain Diets
}

\author{
G. I. Crawford \\ University of Nebraska-Lincoln \\ C. D. Keeler \\ Oklahoma State University, Stillwater
}

J. D. Wagner

Southeast Colorado Research Center, Colorado State University

C. R. Krehbiel

Oklahoma State University, Stillwater, clint.krehbiel@unl.edu

Galen E. Erickson

University of Nebraska-Lincoln, gerickson4@unl.edu

See next page for additional authors

Follow this and additional works at: https://digitalcommons.unl.edu/animalscifacpub

Part of the Animal Sciences Commons

Crawford, G. I.; Keeler, C. D.; Wagner, J. D.; Krehbiel, C. R.; Erickson, Galen E.; Crombie, M. B.; and Nunnery, G. A., "Effects of Calcium Magnesium Carbonate and Roughage Level on Feedlot Performance, Ruminal Metabolism, and Site and Extent of Digestion in Steers Fed High-Grain Diets" (2008). Faculty Papers and Publications in Animal Science. 475.

https://digitalcommons.unl.edu/animalscifacpub/475

This Article is brought to you for free and open access by the Animal Science Department at DigitalCommons@University of Nebraska - Lincoln. It has been accepted for inclusion in Faculty Papers and Publications in Animal Science by an authorized administrator of DigitalCommons@University of Nebraska - Lincoln. 


\section{Authors}

G. I. Crawford, C. D. Keeler, J. D. Wagner, C. R. Krehbiel, Galen E. Erickson, M. B. Crombie, and G. A. Nunnery 


\title{
Effects of calcium magnesium carbonate and roughage level on feedlot performance, ruminal metabolism, and site and extent of digestion in steers fed high-grain diets ${ }^{1,2}$
}

\author{
G. I. Crawford, $*^{3}$ C. D. Keeler, $\dagger$ J. J. Wagner, ${ }^{+}$C. R. Krehbiel, $\dagger^{4}$ G. E. Erickson, $*$ \\ M. B. Crombie,§ and G. A. Nunnery§ \\ *Department of Animal Science, University of Nebraska, Lincoln 68583; †Department of Animal Science, \\ Oklahoma State University, Stillwater 74078; †Southeast Colorado Research Center, \\ Colorado State University, Lamar 81052; and §MIN-AD Inc., Amarillo, TX 79106
}

\begin{abstract}
A feedlot growth performance experiment and 2 metabolism experiments were conducted to evaluate dietary roughage concentration and calcium magnesium carbonate in steers fed a high-grain diet. In Exp. 1, one hundred ninety-two crossbred yearling steers $(320 \pm 10 \mathrm{~kg}$ of initial BW) were fed diets based on steam-flaked corn with $0,0.75$, or $1.5 \% \mathrm{CaMg}\left(\mathrm{CO}_{3}\right)_{2}$. There were no effects $(P \geq 0.13)$ on ADG, DMI, G:F, or total water intake due to $\mathrm{CaMg}\left(\mathrm{CO}_{3}\right)_{2}$. In Exp. 2, five ruminally and duodenally fistulated steers $(263 \pm 9 \mathrm{~kg}$ of initial BW) were used in a $5 \times 5$ Latin square design, with 5 dietary treatments arranged in a $2 \times 2+1$ factorial: 1) $3.8 \%$ dietary roughage and no $\mathrm{CaMg}\left(\mathrm{CO}_{3}\right)_{2} ; 2$ ) $7.6 \%$ dietary roughage and no $\left.\mathrm{CaMg}\left(\mathrm{CO}_{3}\right)_{2} ; 3\right) 11.4 \%$ dietary roughage and no $\mathrm{CaMg}\left(\mathrm{CO}_{3}\right)_{2}$; 4) $3.8 \%$ dietary roughage and $1.5 \% \mathrm{CaMg}\left(\mathrm{CO}_{3}\right)_{2}$; and 5) $7.6 \%$ dietary roughage and $1.5 \% \mathrm{CaMg}\left(\mathrm{CO}_{3}\right)_{2}$. Water consumption was less (quadratic, $P=0.003$ ) when $7.6 \%$ dietary roughage was fed compared with 3.8 or $11.4 \%$ dietary roughage. Intake of DM was not affected $(P \geq 0.16)$ by dietary roughage or by $\mathrm{CaMg}\left(\mathrm{CO}_{3}\right)_{2}$. Poststomach and total tract starch digestion decreased (linear, $P<0.01$ ) as dietary roughage increased. Ruminal $\mathrm{pH}$ tended $(P$ $=0.08)$ to increase as dietary roughage increased but
\end{abstract}

was not affected $(P=0.60)$ by $\mathrm{CaMg}\left(\mathrm{CO}_{3}\right)_{2}$. In Exp. 3, $\mathrm{DMI}$ and ruminal $\mathrm{pH}$ were continuously monitored in a $6 \times 6$ Latin square design using 6 ruminally and duodenally fistulated Holstein steers $(229 \pm 10 \mathrm{~kg}$ of initial BW). A $3 \times 2$ factorial treatment structure was utilized, with factors consisting of dietary roughage concentration (4.5, 9.0, or $13.5 \%)$ and $\mathrm{CaMg}\left(\mathrm{CO}_{3}\right)_{2}$ inclusion $(0$ or $1.0 \%)$ to replace $\mathrm{MgO}$ and partially replace limestone. A dietary roughage $\times \mathrm{CaMg}\left(\mathrm{CO}_{3}\right)_{2}$ interaction $(P$ $=0.01$ ) occurred as steers consuming $13.5 \%$ roughage, $1.0 \% \mathrm{CaMg}\left(\mathrm{CO}_{3}\right)_{2}$ had greater DMI per meal than those consuming $4.5 \%$ dietary roughage, no $\mathrm{CaMg}\left(\mathrm{CO}_{3}\right)_{2}$ and $9.0 \%$ dietary roughage, $1.0 \% \mathrm{CaMg}\left(\mathrm{CO}_{3}\right)_{2}$. Steers consuming $13.5 \%$ dietary roughage, $1.0 \% \mathrm{CaMg}\left(\mathrm{CO}_{3}\right)_{2}$ and $9.0 \%$ dietary roughage, no $\mathrm{CaMg}\left(\mathrm{CO}_{3}\right)_{2}$ had greater meal length ( $\mathrm{min} / \mathrm{meal} ; P=0.01)$ than steers consuming $4.5 \%$ dietary roughage, no $\mathrm{CaMg}\left(\mathrm{CO}_{3}\right)_{2}$. Total tract $\mathrm{OM}$ digestibility decreased linearly $(P=0.01)$, and ruminal $\mathrm{pH}$ increased linearly $(P=0.01)$ with increasing dietary roughage concentration. Inclusion of $\mathrm{CaMg}\left(\mathrm{CO}_{3}\right)_{2}$ can replace limestone and $\mathrm{MgO}$ but did not produce ruminal $\mathrm{pH}$ responses similar to those observed by increasing dietary roughage in high-concentrate diets.

Key words: acidosis, feedlot steer, roughage level, ruminal alkalizer

(C2008 American Society of Animal Science. All rights reserved.

J. Anim. Sci. 2008. 86:2998-3013 doi:10.2527/jas.2007-0070

\section{INTRODUCTION}

\footnotetext{
${ }^{1} \mathrm{~A}$ contribution of the University of Nebraska Agricultural Research Division, supported in part by funds provided through the Hatch Act.

${ }^{2}$ Approved for publication by the director of the Oklahoma Agricultural Experiment Station. This research was supported in part under project $\mathrm{H}-2438$.

${ }^{3}$ Present address: University of Minnesota Extension, 1390 South Highway 15, Suite 201, Hutchinson, MN 55350.

${ }^{4}$ Corresponding author: clint.krehbiel@okstate.edu

Received January 29, 2007.

Accepted June 8, 2008.
}

In a survey of consulting nutritionists servicing the major cattle feeders of the United States, Galyean and Gleghorn (2001) reported that the average beef cattle finishing diet contains $8.9 \%$ roughage. Roughage is one of the most expensive ingredients on an energy basis and is generally added to high-concentrate diets to prevent digestive disturbances (Galyean and Defoor, 2003). Research conducted to limit or eliminate roughage in the diet (Kreikemeier et al., 1990; Loerch, 1991) has generally resulted in decreased DMI and ADG, 
likely due to an increase in the incidence of ruminal acidosis.

Ruminal buffers and alkalizers may provide for a more constant ruminal $\mathrm{pH}$, which may decrease fluctuation in DMI that may either be a cause or effect of acidosis (Cooper et al., 1999). A 4.6\% increase in DMI and a $5.9 \%$ increase in $\mathrm{ADG}$, as well as an increase in ruminal $\mathrm{pH}$ and total tract fiber digestion, were reported by Zinn (1991) when $0.75 \%$ sodium bicarbonate was supplemented to steam-flaked grain diets fed to steers. Farran et al. (2003) observed an increase in ruminal $\mathrm{pH}$ and a decrease in time spent below $\mathrm{pH} 5.6$ when $1.25 \%$ sodium bicarbonate was added to high-moisture, corn-based heifer diets containing $92.5 \%$ concentrate. Others have observed little or no response to ruminal buffer addition to high-concentrate diets (Dunn et al., 1979; Zinn and Borques, 1993).

The avoidance of intake-depressing digestive disorders such as acidosis should ultimately result in fewer days for cattle to reach market weight, and replacing dietary roughage with a ruminal buffer or alkalizer may decrease dietary costs and management problems associated with handling and feeding roughage in feedlots. Therefore, our objective was to evaluate the effects of dietary roughage concentration and $\mathrm{CaMg}\left(\mathrm{CO}_{3}\right)_{2}$ on feedlot performance, ruminal kinetics, and site and extent of digestion in steers fed a high-grain diet.

\section{MATERIALS AND METHODS}

All surgical procedures, postsurgical care, and the experimental protocol had been reviewed and approved by the Oklahoma State University Animal Care and Use Committee, and the experimental protocol was reviewed and approved by the University of Nebraska Animal Care and Use Committee.

\section{Exp. 1}

One hundred ninety-two crossbred yearling steers $(331 \pm 28 \mathrm{~kg}$ of initial BW) purchased in Texas were utilized for this experiment. Cattle were received at the Southern Colorado Research Center in Lamar on April 12, 2001, and had access to long-stemmed hay and water overnight. The following morning, steers were treated for internal and external parasites (Dectomax, Pfizer Animal Health, New York, NY); vaccinated against Clostridium perfringens types $\mathrm{C}$ and $\mathrm{D}$ infections (Ultrabac CD, Pfizer Animal Health) and infectious bovine rhinotracheitis, bovine virus diarrhea, parainfluenza-3, and bovine respiratory syncytial virus infections (Bovishield 4, Pfizer Animal Health); and implanted with estradiol and progesterone (Component E-S, VetLife, Overland Park, KS). At this time, cattle were weighed individually and characterized as 1 of 3 breed types: British crossbred, Continental crossbred, and Brahman crossbred. Cattle were stratified by BW within breed type into 8 BW blocks. Within block, pens of cattle were assigned randomly to 1 of 3 treatments, resulting in 8 pen replicates/treatment and 8 steers/ pen. During the morning after the randomization procedures, cattle were again individually weighed and returned to their respective treatment pens for initiation of the experiment. Initial BW was the average of the 2 individual BW obtained at the beginning of the experiment. Final BW was the average of 2 individual BW obtained on 137 and 138. Cattle were reimplanted with trenbolone acetate and estradiol (Revalor-S, Intervet, Millsboro, DE) on d 56.

Dietary treatments (DM basis) were: 0, 0.75, and $1.5 \% \mathrm{CaMg}\left(\mathrm{CO}_{3}\right)_{2}$ (mined dolomitic limestone, $\mathrm{MIN}-\mathrm{AD}$, MIN-AD Inc., Amarillo, TX). Inclusion of $\mathrm{CaMg}\left(\mathrm{CO}_{3}\right)_{2}$ completely replaced $\mathrm{MgO}$ and partially replaced limestone on a $\mathrm{Ca}$ and $\mathrm{Mg}$ basis; dietary $\mathrm{Ca}$ and $\mathrm{Mg}$ were formulated to be constant (Table 1). Steam-flaked corn was purchased daily from a commercial feedlot and transported $1.5 \mathrm{~km}$ to the research facility at $0600 \mathrm{~h}$. Corn was flaked to a density of $0.35 \mathrm{~kg} / \mathrm{L}$ the evening before transport and stored overnight in overhead finished feed storage bins at the commercial feedlot. Flake density was checked every $2 \mathrm{~h}$ during the steamflaking process. Retention time in the steam chamber was approximately $40 \mathrm{~min}$, and rolls measured $60 \times$ $120 \mathrm{~cm}$.

Cattle were fed $60 \%$ of their daily feed beginning at $0700 \mathrm{~h}$ and $40 \%$ of their daily feed beginning at $1200 \mathrm{~h}$. Feed refusals were weighed and sampled for DM determination whenever feed became spoiled due to adverse weather conditions or whenever cattle were weighed. Feed refusal samples were evaluated for DM by drying the sample for $36 \mathrm{~h}$ at $60^{\circ} \mathrm{C}$. Diets and feed ingredients were sampled periodically throughout the experiment. All diet and feed ingredient samples were analyzed by a commercial feed laboratory (SDK Laboratories, Hutchinson, KS) for DM, CP, NPN, ADF, ether extract, $\mathrm{Ca}, \mathrm{P}, \mathrm{Mg}$, and $\mathrm{K}$. Two pens of the same treatment and similar BW block (blocks 1 and 2, 3 and 4,5 and 6, and 7 and 8) shared a water trough during this experiment, and water intake for each 2 pens was recorded daily.

Two steers were removed from the experiment. One steer from the $0.75 \% \mathrm{CaMg}\left(\mathrm{CO}_{3}\right)_{2}$ treatment showed signs of respiratory disease complex and had a rectal temperature of $41.6^{\circ} \mathrm{C}$. This steer died $3 \mathrm{~d}$ after removal from the experiment. A steer from the $0 \% \mathrm{CaMg}\left(\mathrm{CO}_{3}\right)_{2}$ treatment bloated and was removed from the experiment.

Cattle were slaughtered at a commercial abattoir (Swift and Company, Dumas, TX) after $138 \mathrm{~d}$ on trial for all pens. Carcass data were collected by a commercial carcass data collection firm (Ag-Info-Link, Longmont, CO). On the day of slaughter, measurements of HCW and incidence of abscessed livers were recorded. Longissimus muscle area, 12th-rib backfat, incidence of dark cutters, marbling score, and USDA quality grade (as determined by a USDA grader) were recorded after a 36-h chill. Yield grade was calculated based on components of the USDA yield grade equation. 
Table 1. Composition of diets (DM basis; Exp. 1)

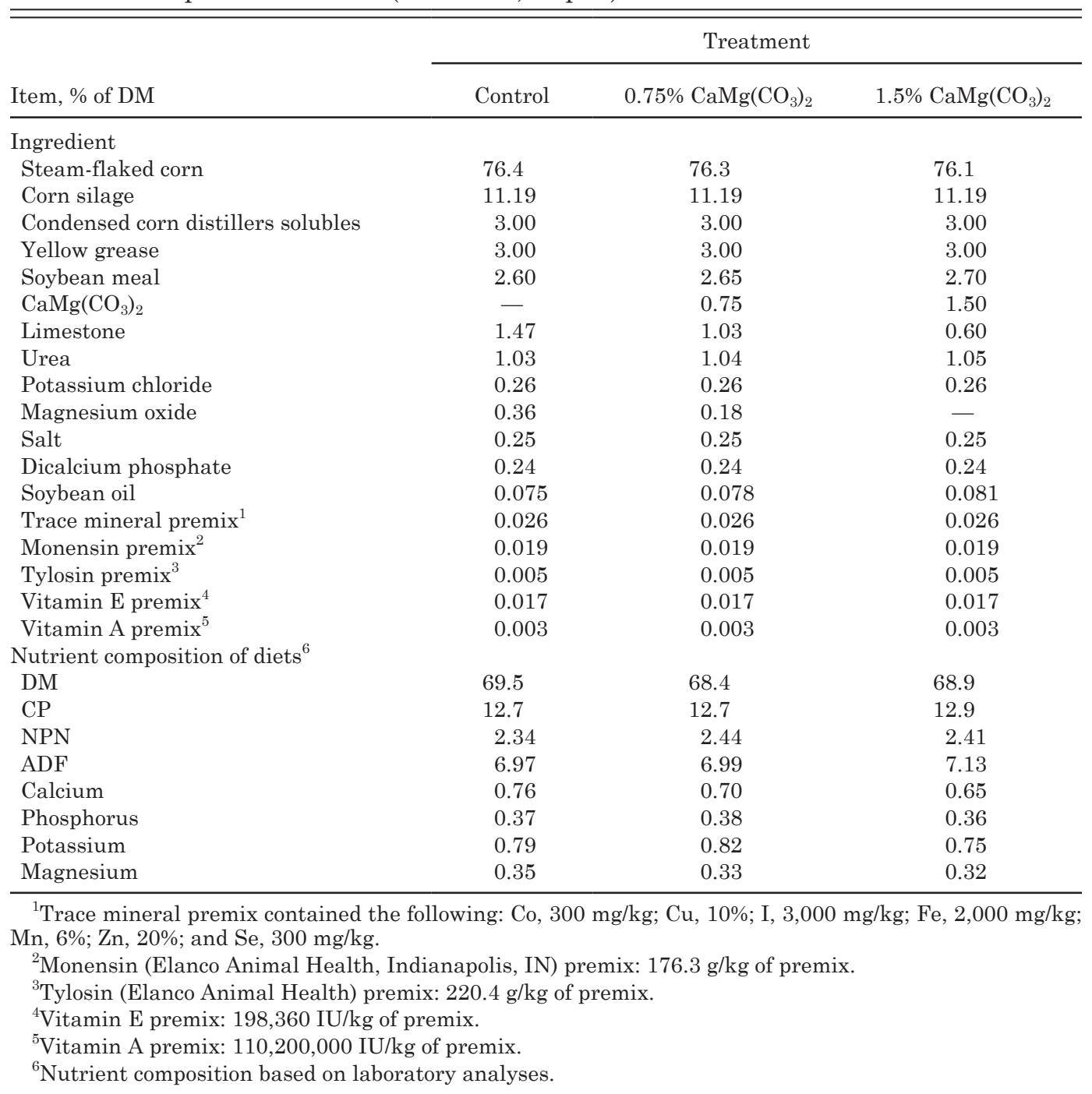

\section{$\operatorname{Exp} .2$}

Five ruminally and duodenally fistulated crossbred steers (263 $\pm 9 \mathrm{~kg}$ of initial BW) were used in a Latin square design experiment to evaluate the effects of dietary roughage concentration and $\mathrm{CaMg}\left(\mathrm{CO}_{3}\right)_{2}$ (MIN$\mathrm{AD}$, MIN-AD Inc.) on ruminal kinetics and site and extent of digestion in steers fed a high-grain diet. Five steers were assigned randomly to 1 of 5 treatments: 1) $3.8 \%$ roughage and no $\left.\mathrm{CaMg}\left(\mathrm{CO}_{3}\right)_{2}, 2\right) 7.6 \%$ roughage and no $\mathrm{CaMg}\left(\mathrm{CO}_{3}\right)_{2}$, 3) $11.4 \%$ roughage and no $\left.\mathrm{CaMg}\left(\mathrm{CO}_{3}\right)_{2}, 4\right) 3.8 \%$ roughage and $1.5 \% \mathrm{CaMg}\left(\mathrm{CO}_{3}\right)_{2}$, or 5) $7.6 \%$ roughage and $1.5 \% \mathrm{CaMg}\left(\mathrm{CO}_{3}\right)_{2}$ (Table 2 ). Steers were housed in individual pens $(3.3 \mathrm{~m} \times 14.6$ $\mathrm{m})$ and had free access to water. The research was conducted at the Southeast Colorado Research Center, Lamar.

All steers were adapted initially to the $7.6 \%$ roughage and no $\mathrm{CaMg}\left(\mathrm{CO}_{3}\right)_{2}$ diet for a period of $12 \mathrm{~d}$ before the experiment. The experiment began on June 16 (d 1 ) and consisted of five 21-d periods. Dry matter intake was calculated daily; all orts were weighed, DM content was determined (method 4.1.06, AOAC, 1997), and
DM refused was subtracted from DM offered. Steers were fed twice daily at 0800 and $1300 \mathrm{~h}$. Chromic oxide $(15 \mathrm{~g} / \mathrm{d})$ was dosed intraruminally daily at 0800 and $1300 \mathrm{~h}$ on $\mathrm{d} 1$ through 20 via gelatin capsules (2/steer) as a marker of digesta flow.

Drinking water was measured into 50-L tubs using a flow meter (Kent water meter, Hackensack, NJ), and water intake was estimated daily at approximately $1200 \mathrm{~h}$. At this time, water refused was measured via graduated cylinder and discarded, and tubs were replenished immediately.

Sampling. Feed was sampled on d 8 through 21 of each period and dried $\left(50^{\circ} \mathrm{C}\right.$ for $\left.48 \mathrm{~h}\right)$. Fecal grab samples were taken on d 17 through 20 of each period at 0700 and $1900 \mathrm{~h}$ and composited by animal within period on an equal wet-weight basis. A portion of the composite for each animal was dried in a forced-air oven $\left(50^{\circ} \mathrm{C}\right.$ for $\left.72 \mathrm{~h}\right)$ and ground to pass a $2-\mathrm{mm}$ screen in a Wiley mill (Thomas Scientific, Swedesboro, NJ) for later determination of $\mathrm{OM}, \mathrm{Cr}$, starch, $\mathrm{NDF}, \mathrm{Ca}, \mathrm{P}$, and $\mathrm{Mg}$. A second portion of the fecal composite was frozen, lyophilized, and used for $\mathrm{N}$ determination. On d 17 and 18 , duodenal contents $(250 \mathrm{~mL})$ were collected every 4 
Table 2. Composition of diets (DM basis; Exp. 2)



${ }^{1}$ Roughage equivalent from corn silage.

${ }^{2}$ Trace mineral premix contained the following: Co, $300 \mathrm{mg} / \mathrm{kg}$; Cu, 10\%; I, 3,000 mg/kg; Fe, 2,000 mg/kg; Mn, 6\%; Zn, 20\%; and Se, 300 mg/ $\mathrm{kg}$.

${ }^{3}$ Monensin (Elanco Animal Health, Indianapolis, IN) premix: $176.3 \mathrm{~g} / \mathrm{kg}$ of premix.

${ }^{4}$ Vitamin E premix: 198,360 IU/kg of premix.

${ }^{5}$ Tylosin (Elanco Animal Health) premix: $220.4 \mathrm{~g} / \mathrm{kg}$ of premix.

${ }^{6}$ Vitamin A premix: 110,200,000 IU/kg of premix.

${ }^{7}$ Values for DM, CP, and NDF are from laboratory analyses. All other values were calculated based on tabular nutrient values for ingredients (NRC, 1996).

$\mathrm{h}$ during a 48-h period; collection times were adjusted on $\mathrm{d} 18$ so that every $2 \mathrm{~h}$ in a 24 -h period were represented. Immediately after collection, duodenal $\mathrm{pH}$ was measured using a portable $\mathrm{pH}$ meter and combination electrode (HI 9024, Hanna Instruments, Ann Arbor, $\mathrm{MI})$. Duodenal contents were frozen $\left(-20^{\circ} \mathrm{C}\right)$ and lyophilized, ground using a coffee grinder (Black \& Decker 117 SmartGrind CBG5 Blades Grinder, Applica Consumer Products, Miramar, FL), and composited within animal and period on a DM basis. On d 17, five whole ruminal content samples were collected at 4 -h intervals (approximately $400 \mathrm{~mL} / \mathrm{sample}$ ) and mixed with $400 \mathrm{~mL}$ of $10 \%$ formaldehyde. Ruminal contents were frozen $\left(-20^{\circ} \mathrm{C}\right)$ and used for bacterial isolation.

On d 20 of each period at approximately $0800 \mathrm{~h}$, Co-EDTA (200 mL containing $3.6 \mathrm{~g}$ of $\mathrm{Co}$; Uden et al., 1980) was pulsed-dosed intraruminally. Ruminal fluid was collected at $0,3,6,9,12,18$, and $24 \mathrm{~h}$ after dosing. Immediately after collection, ruminal fluid $\mathrm{pH}$ was measured using a portable $\mathrm{pH}$ meter and combination electrode (HI 9024, Hanna Instruments). A 10-mL ali- quot was acidified with $0.5 \mathrm{~mL}$ of $6 \mathrm{M} \mathrm{HCl}$ and frozen $\left(-20^{\circ} \mathrm{C}\right)$ for later ammonia analysis. A second $10-\mathrm{mL}$ aliquot was acidified with $2 \mathrm{~mL}$ of $25 \%$ (wt/vol) metaphosphoric acid and frozen $\left(-20^{\circ} \mathrm{C}\right)$ for later VFA analysis. A third $10-\mathrm{mL}$ aliquot was frozen $\left(-20^{\circ} \mathrm{C}\right)$ for $\mathrm{Co}$ analysis.

Laboratory Analyses and Calculations. Ruminal bacteria were isolated using the procedures outlined by Bock et al. (1991). Ground samples of feed, feces, ruminal bacteria, and duodenal contents were analyzed for laboratory DM and OM based on standard procedures (method 4.1.06 and method 4.1.10, respectively, AOAC, 1997). Nitrogen content of feed, lyophilized feces, ruminal bacteria, and lyophilized duodenal contents was determined by the combustion method (Leco NS2000, St. Joseph, MI; method 4.2.10, AOAC 1997). Concentration of NDF in feed, feces, and duodenal contents was determined by the method of Van Soest et al. (1991). Feed, feces, and duodenal starch concentrations were determined using the Megazyme total starch assay procedure (Megazyme International 
Ireland Ltd., Wicklow, Ireland). The between and within assay CV were 5.7 and $<5.0 \%$, respectively, and the sensitivity of the assay is $1 \%$ starch.

Concentrations of $\mathrm{Ca}, \mathrm{Mg}$, and $\mathrm{P}$ in feed, feces, and duodenal contents were determined after acid digestion. Briefly, $1.5 \mathrm{~g}$ of sample was ashed in a $500^{\circ} \mathrm{C}$ ashing oven (Thermolyne Corporation, Dubuque, IA) for 6 $\mathrm{h}$. The ashed sample was dissolved in $5 \mathrm{~mL}$ of concentrated $\mathrm{HNO}_{3}$ and $5 \mathrm{~mL}$ of perchloric acid and boiled on a hot plate for approximately $5 \mathrm{~min}$. The sample was subsequently diluted with distilled water in a $100-\mathrm{mL}$ volumetric flask, and absorbance was measured at 318.1, 279.1, and $178.3 \mathrm{~nm}$ for $\mathrm{Ca}, \mathrm{Mg}$, and $\mathrm{P}$, respectively, with an inductively coupled plasma spectrophotometer (Spectro Analytical Instruments, Fitchburg, MA). For $\mathrm{Cr}$ analyses, fecal and duodenal samples were ashed, digested with a phosphoric acid-manganese sulfate-potassium bromate solution (Williams et al., 1962), and quantified at $267.7 \mathrm{~nm}$ with the same instrument.

Ruminal fluid samples were thawed and centrifuged at $10,000 \times \mathrm{g}$ for $10 \mathrm{~min}$. Concentrations of Co in ruminal fluid samples were determined via inductively coupled plasma spectrophotometer (Spectro Analytical Instruments) analysis at $228.6 \mathrm{~nm}$. Ruminal and duodenal ammonia were determined using procedures outlined by Broderick and Kang (1980) and were quantified using a spectrophotometer (Beckman Instruments, Fullerton, CA). Lyophilized duodenal contents were reconstituted for ammonia analysis using the procedure outlined by Hannah et al. (1991). Analysis of VFA in ruminal fluid was conducted using GLC (N611-9000, PerkinElmer, Waltham, MA) as outlined by Goetsch and Galyean (1983).

Duodenal contents and bacterial isolates were analyzed for purine concentrations to determine microbial protein flow using a modified Zinn and Owens (1986) procedure that used a more diluted $\mathrm{HClO}_{4}$ to hydrolyze the material containing purines. The $\mathrm{HClO}_{4}(70 \%)$ was diluted with water to prepare a solution of $2 \mathrm{M} \mathrm{HClO}_{4}$ for the extraction procedure.

Fecal DM output was calculated as $\mathrm{Cr}$ consumed (g/d) divided by $\mathrm{Cr}$ concentration in feces ( $\mathrm{g} / \mathrm{g}$ of $\mathrm{DM})$. Stomach and poststomach digestibilities were estimated using the marker ratio technique (Merchen, 1988) with $\mathrm{Cr}$ as the reference. Liquid dilution rate of Co was calculated by regressing the natural log of Co concentration on time after dosing. Retention time and time for $50 \%$ turnover were calculated as $0.693 /$ dilution rate and 1 /dilution rate, respectively. Ruminal volume was calculated by dividing the Co dose by ruminal concentration extrapolated to $0 \mathrm{~h}$, and ruminal outflow rate was calculated as ruminal volume multiplied by the dilution rate. Area below pH 6.0 and 5.6 was calculated by subtracting each ruminal $\mathrm{pH}$ value recorded throughout the day from 6.0 and 5.6. All positive values for the day were then summed, and area of ruminal $\mathrm{pH}$ below a value of 6.0 and 5.6 represents the units of magnitude of $\mathrm{pH}$ below 6.0 and $5.6 \times$ minute.

\section{Exp. 3}

Six ruminally and duodenally fistulated Holstein steer calves (229 $\pm 10 \mathrm{~kg}$ of initial $\mathrm{BW})$ were assigned randomly to 1 of 6 treatments in a $3 \times 2$ factorial arrangement, using a $6 \times 6$ Latin square experimental design. After a 21 -d adaptation to a $95.5 \%$ concentrate diet, steers were assigned to treatment. Steers received $4.5,9.0$, or $13.5 \%$ roughage with or without $1.0 \% \mathrm{CaMg}\left(\mathrm{CO}_{3}\right)_{2}$ (Table 3). The concentrate portion of each treatment contained a 80:20 ratio of high-moisture corn and dry-rolled corn, and the roughage was alfalfa hay. All diets contained $33 \mathrm{mg} / \mathrm{kg}$ of monensin and $12 \mathrm{mg} / \mathrm{kg}$ of tylosin, and $\mathrm{CaMg}\left(\mathrm{CO}_{3}\right)_{2}$ was provided in a dry supplement. Steers were not implanted.

Ruminal and duodenal fistulation surgeries were performed at Oklahoma State University, and steers were transported to the University of Nebraska, Lincoln, after a 1-mo recovery period. Periods were $21 \mathrm{~d}$ in length (12-d diet adaptation and 9-d data collection), and all animals were fed for ad libitum intake. Bunks were assessed daily at $0730 \mathrm{~h}$, and feed offerings were adjusted accordingly for feeding at $0800 \mathrm{~h}$. Steers were fed individually in slotted-floor pens $(1.5 \times 2.4 \mathrm{~m})$ in a temperature-controlled room $\left(25^{\circ} \mathrm{C}\right)$ from $\mathrm{d} 1$ through 12 and $d 18$ through 21 of each period. In the afternoon of $\mathrm{d} 12$, steers were moved and tethered in individual metabolism stalls in the same room and were allowed to acclimate to stalls overnight. Beginning on d 13, steers were fed in individual feed bunks suspended from load cells (Omega, Stamford, CT) connected to a computer equipped with software allowing for continuous data acquisition (Labtech, Wilmington, MA). Feed weight in each bunk was recorded once every minute and continuously stored for each steer throughout the day. Feed intake measurements (d 13 through 18 of each period) included DMI, rate of DMI, number of meals per day, average meal size, time spent eating, and average meal length (Cooper et al., 1999; Erickson et al., 2003).

Before feeding on d 13, submersible $\mathrm{pH}$ probes (Jenco, San Diego, CA; Sensorex, Garden Grove, CA) were placed into the rumen of each steer through the ruminal fistula and remained in place through the morning of $\mathrm{d} 18$. Each $\mathrm{pH}$ probe was encased in a weighted, 4-wire metal shroud to maintain the electrode in a stationary suspended position approximately $15 \mathrm{~cm}$ above the floor of the rumen. Electrodes were linked directly to a computer equipped with data acquisition software to record ruminal $\mathrm{pH}$ every $6 \mathrm{~s}$ and averaged every minute throughout the $\mathrm{pH}$ data collection phase. On $\mathrm{d} 18$ of each period, $\mathrm{pH}$ electrodes were removed from the rumen, and steers were returned to their respective free stalls. Ruminal $\mathrm{pH}$ measurements included average, maximum, and minimum $\mathrm{pH}$; time spent below ruminal $\mathrm{pH} 5.3$ and 5.6; area of ruminal $\mathrm{pH}$ below 5.3 and 5.6 (time below $\times$ magnitude below); and magnitude of pH change (Cooper et al., 1999; Erickson et al., 2003). In addition, daily variance in ruminal $\mathrm{pH}$ was calculated as the square of the sample standard deviation. 
Table 3. Composition of diets (DM basis; Exp. 3)

\begin{tabular}{|c|c|c|c|c|c|c|}
\hline \multirow[b]{2}{*}{ Item, \% of DM } & \multicolumn{3}{|c|}{ No $\mathrm{CaMg}\left(\mathrm{CO}_{3}\right)_{2}$} & \multicolumn{3}{|c|}{$1.0 \% \mathrm{CaMg}\left(\mathrm{CO}_{3}\right)_{2}$} \\
\hline & $4.5 \%^{1}$ & $9.0 \%{ }^{1}$ & $13.5 \%{ }^{1}$ & $4.5 \%$ & $9.0 \%$ & $13.5 \%$ \\
\hline \multicolumn{7}{|l|}{ Ingredient } \\
\hline High-moisture corn & 65.2 & 61.6 & 58.0 & 65.2 & 61.6 & 58.0 \\
\hline Dry-rolled corn & 16.3 & 15.4 & 14.5 & 16.3 & 15.4 & 14.5 \\
\hline Alfalfa hay & 4.5 & 9.0 & 13.5 & 4.5 & 9.0 & 13.5 \\
\hline Soypass $^{2}$ & 5.0 & 5.0 & 5.0 & 5.0 & 5.0 & 5.0 \\
\hline Molasses & 5.0 & 5.0 & 5.0 & 5.0 & 5.0 & 5.0 \\
\hline Limestone & 1.45 & 1.29 & 1.14 & 0.91 & 0.75 & 0.59 \\
\hline Urea & 1.05 & 0.93 & 0.80 & 1.05 & 0.93 & 0.80 \\
\hline $\mathrm{CaMg}\left(\mathrm{CO}_{3}\right)_{2}$ & - & - & - & 1.00 & 1.00 & 1.00 \\
\hline Potassium chloride & 0.48 & 0.36 & 0.23 & 0.49 & 0.36 & 0.24 \\
\hline Fine ground corn & 0.36 & 0.78 & 1.20 & 0.03 & 0.44 & 0.85 \\
\hline Magnesium oxide & 0.13 & 0.12 & 0.11 & - & - & - \\
\hline Salt & 0.30 & 0.30 & 0.30 & 0.30 & 0.30 & 0.30 \\
\hline Tallow & 0.13 & 0.13 & 0.13 & 0.13 & 0.13 & 0.13 \\
\hline Monensin premix ${ }^{3}$ & 0.02 & 0.02 & 0.02 & 0.02 & 0.02 & 0.02 \\
\hline Tylosin premix ${ }^{4}$ & 0.005 & 0.005 & 0.005 & 0.005 & 0.005 & 0.005 \\
\hline Vitamin premix ${ }^{5}$ & 0.01 & 0.01 & 0.01 & 0.01 & 0.01 & 0.01 \\
\hline \multicolumn{7}{|c|}{ Nutrient composition of diets ${ }^{6}$} \\
\hline DM & 77.0 & 77.0 & 77.7 & 77.1 & 77.1 & 78.0 \\
\hline $\mathrm{CP}$ & 14.8 & 15.1 & 15.3 & 15.0 & 15.0 & 15.4 \\
\hline NDF & 13.4 & 15.2 & 17.1 & 13.6 & 14.8 & 17.1 \\
\hline Calcium & 0.85 & 0.83 & 0.85 & 0.83 & 0.85 & 0.85 \\
\hline Phosphorus & 0.31 & 0.31 & 0.30 & 0.30 & 0.30 & 0.30 \\
\hline Potassium & 0.89 & 0.90 & 0.90 & 0.89 & 0.90 & 0.90 \\
\hline Magnesium & 0.25 & 0.26 & 0.26 & 0.27 & 0.27 & 0.28 \\
\hline
\end{tabular}

${ }^{1}$ Alfalfa hay.

${ }^{2}$ Maillard-reacted soybean meal (undegradable intake protein $=74 \%$ of CP; LignoTech, Rothschild, WI).

${ }^{3}$ Monensin (Elanco Animal Health, Indianapolis, IN) premix: $176.3 \mathrm{~g} / \mathrm{kg}$ of premix.

${ }^{4}$ Tylosin (Elanco Animal Health) premix: $220.4 \mathrm{~g} / \mathrm{kg}$ of premix.

${ }^{5}$ Vitamin premix (per gram of premix): 15,000 IU of vitamin A, 3,000 IU of vitamin D, and 3.7 IU of vitamin E.

${ }^{6}$ Values are based on laboratory analyses.

Variance in ruminal $\mathrm{pH}$ was calculated for each day of the 5 - $d$ collection period, and the average of the $5 \mathrm{~d}$ was used for statistical analysis.

Chromic oxide was used as an indigestible marker for estimating fecal output (Merchen, 1988). Boluses containing $7.5 \mathrm{~g}$ of $\mathrm{Cr}_{2} \mathrm{O}_{3}$ were inserted through the ruminal fistula twice daily $(0700$ and $1900 \mathrm{~h})$ from $\mathrm{d}$ 8 through 16 of each period. Dysprosium chloride was mordanted to alfalfa hay according to the procedures of Ellis and Beever (1984) and Sindt et al. (1993) and pulse-dosed (56.5 mg/g of alfalfa) at $0800 \mathrm{~h}$ on d 13 of each period to measure ruminal solids dilution. To determine ruminal liquid dilution, a Co-EDTA solution $(100 \mathrm{~mL} ; 1.8 \mathrm{~g}$ of $\mathrm{Co})$ was pulse-dosed immediately before feeding $(0800 \mathrm{~h})$ on d 20 of each period (Uden et al., 1980). Urinary creatinine was used as a marker to estimate urine volume (Whittet et al., 2004), and the ratio of the urinary purine derivatives (allantoin plus uric acid) to creatinine was used to estimate relative differences in microbial protein production (Shingfield and Offer, 1998).

Sampling. Each experimental diet was sampled daily, composited by period, and dried in a $60^{\circ} \mathrm{C}$ oven for $48 \mathrm{~h}$ to determine DM content. All feed refusals were removed and quantified before feeding. During the collection period, orts for individual steers were sampled daily ( $10 \%$ of daily refusal weight), composited by period, and frozen $\left(-20^{\circ} \mathrm{C}\right)$ for later analyses. An additional orts sample $(100 \mathrm{~g})$ was dried in a $60^{\circ} \mathrm{C}$ oven for $48 \mathrm{~h}$ to determine DM content.

Spot samples of urine were collected on d 19 (0200, 0600, 1000, 1400, 1800, and $2200 \mathrm{~h})$ and on d 20 (0400, $0800,1200,1600,2000$, and $2400 \mathrm{~h}$ ) to represent every $2 \mathrm{~h}$ in a 24 -h day. Urine samples were collected using a 2-L collection container placed over the sheath and attached via a strap fastened around the body of the steer. Collection containers were attached to the steers for a maximum of $30 \mathrm{~min}$. Urine was filtered through 2 layers of cheesecloth into $50-\mathrm{mL}$ conical tubes and immediately frozen $\left(-20^{\circ} \mathrm{C}\right)$ for later analyses. Fecal grab samples were collected 0,6 , and $12 \mathrm{~h}$ after feeding on d 14 through 17 for $\mathrm{Cr}_{2} \mathrm{O}_{3}$ analyses. For each steer, fecal samples were composited daily on an equal wet-weight basis and frozen $\left(-20^{\circ} \mathrm{C}\right)$ for later analyses. Fecal samples for Dy analyses were collected at 0, 16, 20, 24, 30, 36, 44, 52, 64, 80, and $96 \mathrm{~h}$ after dosing. Fecal samples were then dried in a $60^{\circ} \mathrm{C}$ oven for $48 \mathrm{~h}$ and ground to pass through a 1-mm screen. Ruminal fluid samples $(50 \mathrm{~mL})$ were collected from each steer immediately before Co-EDTA pulse dose and 3, 6, 9, 
12,18 , and $24 \mathrm{~h}$ after dosing using a suction strainer (Raun and Burroughs, 1962). Ruminal fluid samples were frozen $\left(-20^{\circ} \mathrm{C}\right)$ for later analyses.

Laboratory Analyses and Calculations. Rate of intake was calculated from feed disappearance from bunks equipped with load cells. Feed weights were recorded for each minute during each day of collection. Feed disappearance was curvilinear similar to previous work described by Cooper et al. (1999). Therefore, data were transformed using a natural log transformation, and the slope was calculated to determine rate of intake with units of percentage per hour. Average ruminal $\mathrm{pH}$ was calculated by averaging 1,440 measurements recorded during each 24 -h collection day. Time below $\mathrm{pH} 5.6$ and 5.3 was calculated by summing the total minutes in each 24-h measurement day, in which $\mathrm{pH}$ was less than 5.6 and 5.3. Area below $\mathrm{pH} 5.6$ and 5.3 was calculated as described for Exp. 2.

Ort, diet, feed ingredient, and fecal samples were lyophilized, ground, and analyzed for DM, OM, N, and $\mathrm{NDF}$ as described for Exp. 2. For Cr analyses, fecal samples were ashed and digested as described for Exp. 2 and analyzed using an atomic absorption spectrophotometer (SpectrAA-30, Varian Inc., Palo Alto, CA) with an air-acetylene flame. Ruminal fluid VFA and ammonia concentrations were determined as described for Exp. 2. Starch content of ort, diet, feed ingredient, and fecal samples was determined according to procedures of Zinn (1990). A SpectraMax 250 spectrophotometer (Molecular Devices Corp., Sunnyvale, CA) was used for ammonia and starch determination.

Concentrations of $\mathrm{Ca}, \mathrm{Mg}$, and $\mathrm{P}$ in ort, diet, feed ingredient, fecal, and urine samples and concentrations of $\mathrm{Co}$ in ruminal fluid were analyzed as described for Exp. 2. Concentrations of Dy in fecal samples were determined via inductively coupled plasma spectrophotometer (Spectro Analytical Instruments) analysis at $353.2 \mathrm{~nm}$. Liquid (Co) and solids (Dy) dilution rates were calculated according to the procedures of Grovum and Williams (1973).

Urine samples were diluted with 1 part urine and 39 parts urine diluent [volume basis; $10.0 \mathrm{~m} M$ 1-heptanesulfonic acid in $7.5 \mathrm{~m} M$ ammonium phosphate buffer ( $\mathrm{pH}$ 2.1)], and purine derivatives and creatinine were analyzed by HPLC (Waters Corp., Milford, MA) according to the procedures of Shingfield and Offer (1999).

\section{Statistical Analyses}

Exp. 1. Feedlot performance, HCW, dressing percentage, marbling score, 12th-rib fat thickness, LM area, and calculated yield grade were treated as continuous data and analyzed using PROC MIXED (SAS Inst. Inc., Cary, NC). Liver abscess rate and USDA quality grade data were considered as categorical data and analyzed using the PROC GLIMMIX (SAS Inst. Inc.). For all models, pen was the experimental unit, treatment was considered a fixed class variable, and block was considered a random class variable. Orthog- onal contrasts were used to test linear and quadratic effects of $\mathrm{CaMg}\left(\mathrm{CO}_{3}\right)_{2}$.

For water intake data, water troughs were considered experimental units. Therefore, only 4 replicates for each treatment were analyzed. Water intake data were analyzed using the MIXED procedure of SAS for repeated measures using an autoregressive covariance structure as described by Littell et al. (2000). Treatment and water trough were considered class variables, and day of experiment was considered a continuous variable. Treatment, day of experiment, and the treatment $\times$ day, day $\times$ day, and treatment $\times$ day $x$ day interactions were included in the model as fixed effects, and water trough within treatment was considered the subject of the repeated statement. Orthogonal contrasts were used to test linear and quadratic effects of $\mathrm{CaMg}\left(\mathrm{CO}_{3}\right)_{2}$. Results are discussed as significant if $P$ $\leq 0.05$ and as a tendency if $P>0.05$ and $P \leq 0.10$.

Exp. 2. All statistical analyses were performed using the PROC MIXED of SAS. Intake, digestibility, and digesta kinetics data were analyzed as a Latin square design with a $2 \times 2+1$ arrangement of treatments. The model included fixed effects of dietary roughage concentration, $\mathrm{CaMg}\left(\mathrm{CO}_{3}\right)_{2}$, roughage concentration $\times$ $\mathrm{CaMg}\left(\mathrm{CO}_{3}\right)_{2}$, and period. Steer was included in the model as a random variable. For data repeated over time (ruminal $\mathrm{pH}$, ammonia, and VFA), the model included fixed effects of roughage concentration, $\mathrm{CaMg}\left(\mathrm{CO}_{3}\right)_{2}$, roughage concentration $\times \mathrm{CaMg}\left(\mathrm{CO}_{3}\right)_{2}$, time, roughage concentration $\times$ time, $\mathrm{CaMg}\left(\mathrm{CO}_{3}\right)_{2} \times$ time, roughage concentration $\times \mathrm{CaMg}\left(\mathrm{CO}_{3}\right)_{2} \times$ time, and period; an autoregressive covariance structure was determined to provide the best fit to the majority of response variables and therefore was used. Steer was included in the model as a random variable. Time was included as the repeated variable, and animal within period $x$ treatment was the subject of the repeated statement. When a significant $(P \leq 0.05) F$-test for roughage was observed, contrasts were used to test for linear and quadratic effects of dietary roughage concentration. Results are discussed as significant if $P \leq 0.05$ and as a tendency if $P>0.05$ and $P \leq 0.10$.

Exp. 3. Data were analyzed as a $3 \times 2$ factorial treatment arrangement and Latin square experimental design using PROC MIXED of SAS. For total tract digestibility and ruminal dilution analyses, the model included period, alfalfa concentration, $\mathrm{CaMg}\left(\mathrm{CO}_{3}\right)_{2}$ inclusion, and alfalfa concentration $\times \mathrm{CaMg}\left(\mathrm{CO}_{3}\right)_{2}$ interaction. Intake, ruminal, and urinary data were analyzed as repeated measures. An autoregressive covariance structure was utilized for DMI, DMI/meal, meals/ day, time eating/day, time eating/meal, average and maximum ruminal $\mathrm{pH}$, time and area below $\mathrm{pH} 5.6$ and 5.3, total ruminal VFA, individual VFA molar proportions, and liquid and solids dilution rate. A Toeplitz structure was utilized for rate of DMI, minimum ruminal $\mathrm{pH}, \mathrm{pH}$ range and variance, acetate:propionate ratio, ruminal ammonia concentration, and urinary purine derivative:creatinine ratio. For intake and ru- 
Table 4. Effect of dietary $\mathrm{CaMg}\left(\mathrm{CO}_{3}\right)_{2}$ concentration on feedlot performance, water tank and feed bunk behavior, and carcass characteristics (Exp. 1)

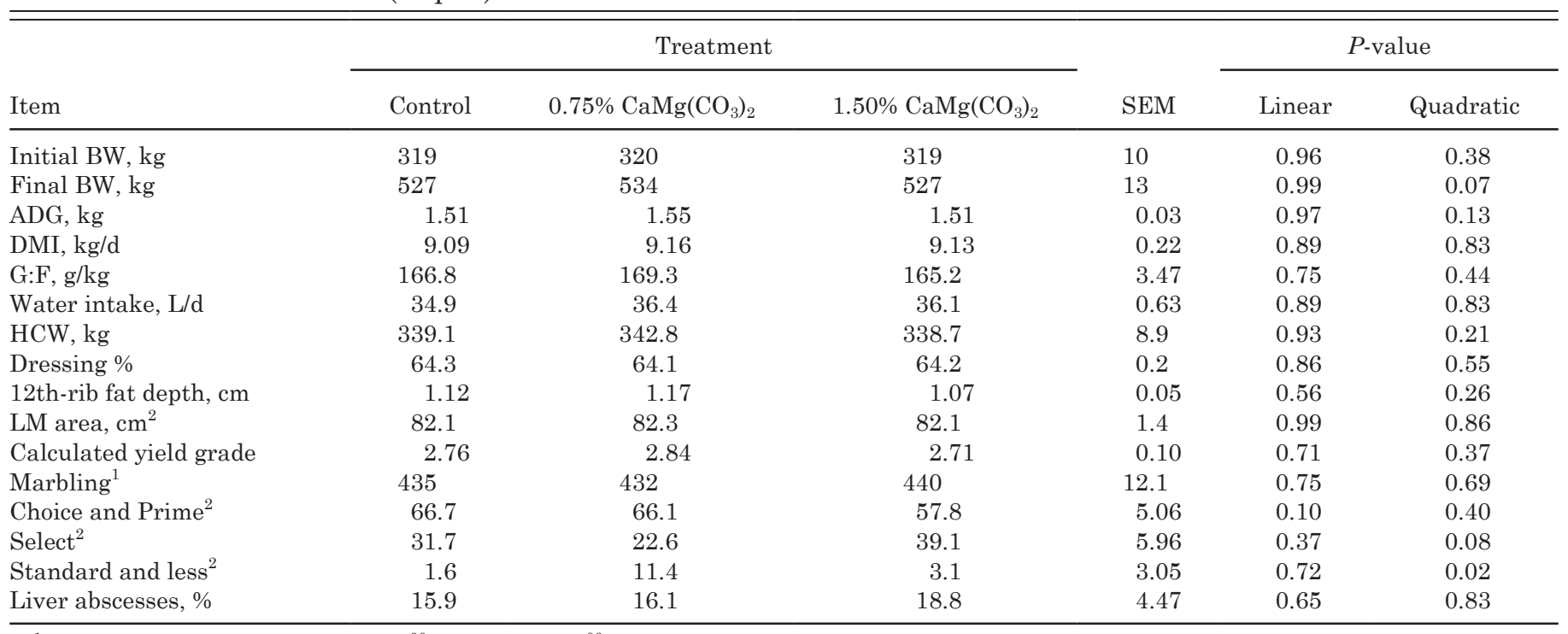

${ }^{1}$ Marbling score units: $400=$ small $^{00} ; 500=$ modest $^{00}$.

${ }^{2}$ Percentage of individual carcasses qualified for the USDA quality grade category.

minal $\mathrm{pH}$ analyses, the model consisted of period, alfalfa concentration, $\mathrm{CaMg}\left(\mathrm{CO}_{3}\right)_{2}$ inclusion, alfalfa concentration $\times \mathrm{CaMg}\left(\mathrm{CO}_{3}\right)_{2}$ inclusion, day of collection period, alfalfa concentration $\times$ day of collection period, $\mathrm{CaMg}\left(\mathrm{CO}_{3}\right)_{2}$ inclusion $\times$ day of collection period, and alfalfa concentration $\times \mathrm{CaMg}\left(\mathrm{CO}_{3}\right)_{2}$ inclusion $\times$ day of collection period. For VFA, ruminal ammonia, and urine analyses, the model consisted of period, alfalfa concentration, $\mathrm{CaMg}\left(\mathrm{CO}_{3}\right)_{2}$ inclusion, alfalfa concentration $\times \mathrm{CaMg}\left(\mathrm{CO}_{3}\right)_{2}$ inclusion, time of collection, alfalfa concentration $\times$ time of collection, $\mathrm{CaMg}\left(\mathrm{CO}_{3}\right)_{2}$ inclusion $\times$ time of collection, and alfalfa concentration $\times \mathrm{CaMg}\left(\mathrm{CO}_{3}\right)_{2}$ inclusion $\times$ time of collection. All models included steer and steer $\times$ alfalfa concentration $\times \mathrm{CaMg}\left(\mathrm{CO}_{3}\right)_{2} \times$ period as random effects. When an alfalfa concentration $\times \mathrm{CaMg}\left(\mathrm{CO}_{3}\right)_{2}$ interaction was significant, least squares means were separated using the PDIFF statement in SAS when protected by a significant $(P \leq 0.10) F$-test. Alfalfa concentration was analyzed for linear and quadratic responses using the contrast statement in SAS. Results are discussed as significant if $P \leq 0.05$ and as a tendency if $P>0.05$ and $P \leq 0.10$.

\section{RESULTS}

\section{Exp. 1}

A tendency $(P=0.07)$ for a quadratic response to treatment was observed for final BW (Table 4). Steers fed $0.75 \% \mathrm{CaMg}\left(\mathrm{CO}_{3}\right)_{2}$ had $6 \mathrm{~kg}$ greater final $\mathrm{BW}$ than control steers or steers fed $1.5 \% \mathrm{CaMg}\left(\mathrm{CO}_{3}\right)_{2}$. Dry matter intake, ADG, and G:F did not differ $(P \geq 0.13)$ among treatments. No differences $(P \geq 0.28)$ were observed for daily water intake, which averaged $35.8 \pm$ $0.63 \mathrm{~L} / \mathrm{d}$ across all treatments.
Hot carcass weight was not affected $(P \geq 0.21)$ by increasing $\mathrm{CaMg}\left(\mathrm{CO}_{3}\right)_{2}$ (Table 4). In addition, no differences $(P \geq 0.26)$ were observed for 12 th-rib fat depth, LM area, calculated yield grade, and marbling score. There was a linear $(P=0.10)$ trend for the likelihood that an individual carcass qualified for the USDA Choice or Prime grade to decrease as the concentration of $\mathrm{CaMg}\left(\mathrm{CO}_{3}\right)_{2}$ increased in the diet. The likelihood that an individual carcass graded USDA Select tended to be less (quadratic effect, $P=0.08$ ) for the $0.75 \%$ $\mathrm{CaMg}\left(\mathrm{CO}_{3}\right)_{2}$ treatment compared with the control or $1.5 \% \mathrm{CaMg}\left(\mathrm{CO}_{3}\right)_{2}$ treatments. Carcasses from steers fed the $0.75 \% \mathrm{CaMg}\left(\mathrm{CO}_{3}\right)_{2}$ diet were more (quadratic effect, $P=0.02$ ) likely to grade USDA Standard or less as compared with the control or $1.5 \%$ treatments. No differences $(P \geq 0.65)$ were observed in the likelihood that an individual liver was abscessed, with 15.9, 16.1, and $18.8 \%$ abscessed livers observed for the control, $0.75 \% \mathrm{CaMg}\left(\mathrm{CO}_{3}\right)_{2}$, and $1.5 \% \mathrm{CaMg}\left(\mathrm{CO}_{3}\right)_{2}$ treatments, respectively.

\section{Exp. 2}

Daily water intake (Table 5) was least for steers fed $7.6 \%$ roughage (quadratic, $P=0.003$ ). In addition, there was a tendency $(P=0.06)$ for an interaction between roughage concentration and $\mathrm{CaMg}\left(\mathrm{CO}_{3}\right)_{2}$ for daily water intake. This resulted from greater water intake for steers consuming $3.8 \%$ roughage and $\mathrm{CaMg}\left(\mathrm{CO}_{3}\right)_{2}$ and less water intake for steers consuming $7.6 \%$ roughage and $\mathrm{CaMg}\left(\mathrm{CO}_{3}\right)_{2}$, compared with steers consuming the same roughage concentrations with no $\mathrm{CaMg}\left(\mathrm{CO}_{3}\right)_{2}$. Calcium magnesium carbonate supplementation and dietary roughage concentration had no effect $(P \geq 0.11)$ on DM, OM, or N intakes. However, NDF intake increased (linear roughage effect, $P<0.01$ ) as rough- 
Table 5. Site and extent of nutrient digestion in steers fed increasing roughage with or without $\mathrm{CaMg}\left(\mathrm{CO}_{3}\right)_{2}\left(\mathrm{Exp}_{\text {. }}\right.$ 2)

\begin{tabular}{|c|c|c|c|c|c|c|c|c|c|}
\hline \multirow[b]{2}{*}{ Item } & \multicolumn{3}{|c|}{ No $\mathrm{CaMg}\left(\mathrm{CO}_{3}\right)_{2}$} & \multicolumn{2}{|c|}{$1 \% \mathrm{CaMg}\left(\mathrm{CO}_{3}\right)_{2}$} & \multirow[b]{2}{*}{ SEM } & \multicolumn{3}{|c|}{$P$-value } \\
\hline & $3.8 \%{ }^{1}$ & $7.6 \%^{1}$ & $11.4 \%^{1}$ & $3.8 \%$ & $7.6 \%$ & & $\begin{array}{l}\text { Roughage } \\
\text { (R) }\end{array}$ & $\mathrm{CaMg}\left(\mathrm{CO}_{3}\right)_{2}$ & $\mathrm{R} \times \mathrm{CaMg}\left(\mathrm{CO}_{3}\right)_{2}$ \\
\hline Water intake, ${ }^{2} \mathrm{~L} / \mathrm{d}$ & 31.8 & 30.3 & 32.8 & 33.2 & 26.2 & 2.6 & $<0.01$ & 0.11 & 0.06 \\
\hline \multicolumn{10}{|l|}{ Nutrient intake, g/d } \\
\hline DM & 6,156 & 6,864 & 7,501 & 7,004 & 6,600 & 563 & 0.16 & 0.91 & 0.19 \\
\hline Starch & 3,471 & 4,061 & 3,988 & 4,016 & 3,748 & 313 & 0.59 & 0.83 & 0.09 \\
\hline $\mathrm{N}$ & 119 & 131 & 149 & 137 & 136 & 11.2 & 0.11 & 0.63 & 0.46 \\
\hline \multicolumn{10}{|l|}{ Duodenal flow, g/d } \\
\hline $\mathrm{OM}$ & 2,668 & 2,840 & 3,103 & 3,390 & 2,987 & 411 & 0.74 & 0.13 & 0.24 \\
\hline $\mathrm{NDF}$ & 919 & 1,010 & 901 & 918 & 656 & 235 & 0.83 & 0.24 & 0.32 \\
\hline Starch & 730 & 681 & 908 & 1,035 & 888 & 270 & 0.74 & 0.21 & 0.77 \\
\hline $\mathrm{OM}$ & 54.5 & 56.4 & 56.5 & 50.6 & 54.6 & 4.41 & 0.49 & 0.27 & 0.77 \\
\hline $\mathrm{NDF}$ & 16.0 & 25.5 & 38.6 & 23.9 & 42.9 & 19.4 & 0.44 & 0.58 & 0.76 \\
\hline Starch & 79.9 & 85.3 & 78.7 & 76.7 & 79.7 & 5.17 & 0.36 & 0.28 & 0.72 \\
\hline Feed N & 58.4 & 60.3 & 66.9 & 59.1 & 62.1 & 5.14 & 0.38 & 0.78 & 0.92 \\
\hline $\begin{array}{l}\text { Microbial efficiency, g of } \mathrm{N} / \mathrm{kg} \\
\text { of OM truly fermented }\end{array}$ & 21.8 & 18.6 & 18.5 & 24.2 & 20.2 & 2.80 & 0.21 & 0.25 & 0.87 \\
\hline \multicolumn{10}{|l|}{ Fecal output, g/d } \\
\hline $\mathrm{OM}$ & 746 & 857 & 1,070 & 700 & 1,058 & 176 & 0.06 & 0.91 & 0.34 \\
\hline $\mathrm{NDF}$ & 588 & 636 & 682 & 575 & 734 & 103 & 0.32 & 0.76 & 0.51 \\
\hline Starch & 25 & 32 & 53 & 33 & 43 & 13.5 & 0.09 & 0.85 & 0.85 \\
\hline $\mathrm{N}$ & 28 & 30 & 36 & 25 & 35 & 6.4 & 0.20 & 0.81 & 0.41 \\
\hline \multicolumn{10}{|l|}{ Poststomach digestion, \% } \\
\hline $\mathrm{N}$ & 76.6 & 75.0 & 71.6 & 83.1 & 69.8 & 5.05 & 0.11 & 0.56 & 0.17 \\
\hline \multicolumn{10}{|l|}{ Total tract digestion, \% } \\
\hline $\mathrm{OM}^{3}$ & 87.2 & 86.9 & 85.2 & 90.2 & 83.4 & 1.97 & 0.05 & 0.78 & 0.06 \\
\hline NDF & 45.4 & 51.8 & 53.9 & 54.7 & 38.7 & 8.95 & 0.54 & 0.54 & 0.16 \\
\hline $\mathrm{Starch}^{4}$ & 99.3 & 99.3 & 98.8 & 99.3 & 99.0 & 0.24 & 0.02 & 0.83 & 0.42 \\
\hline $\mathrm{N}$ & 76.6 & 77.2 & 76.6 & 82.5 & 73.8 & 3.77 & 0.36 & 0.62 & 0.15 \\
\hline
\end{tabular}

age concentration increased. Starch intake tended ( $P$ $=0.09)$ to respond with a roughage concentration $\times$ $\mathrm{CaMg}\left(\mathrm{CO}_{3}\right)_{2}$ interaction, resulting from numerically greater starch intake when 7.6 vs. $3.8 \%$ roughage with no $\mathrm{CaMg}\left(\mathrm{CO}_{3}\right)_{2}$ was fed and numerically less starch intake when 7.6 vs. $3.8 \%$ roughage with $\mathrm{CaMg}\left(\mathrm{CO}_{3}\right)_{2}$ was fed.

Duodenal flow and ruminal digestion of nutrients (Table 5) were generally not affected $(P>0.10)$ by dietary roughage concentration or $\mathrm{CaMg}\left(\mathrm{CO}_{3}\right)_{2}$, although duodenal flow of ammonia $\mathrm{N}$ tended $(P=0.10)$ to increase as roughage concentration increased. Fecal out- put of OM $(P=0.06)$ and starch $(P=0.09)$ tended to increase as roughage concentration increased, whereas fecal output of NDF and N was not different $(P \geq$ $0.20)$ among treatments. Poststomach digestion (\% of intake) of OM $(P=0.08)$ and $\mathrm{N}(P=0.09)$ tended to decrease as roughage concentration increased. Similar results were observed when poststomach digestion was expressed as a percentage leaving the abomasum. Percentage of starch leaving the abomasum that was digested in the poststomach decreased (linear roughage effect, $P<0.01)$ with increasing roughage, and there was a tendency $(P=0.07)$ for poststomach starch di- 
Table 6. Mineral intake, excretion, and digestion in steers fed increasing roughage with or without $\mathrm{CaMg}\left(\mathrm{CO}_{3}\right)_{2}$ (Exp. 2)

\begin{tabular}{|c|c|c|c|c|c|c|c|c|c|}
\hline Item & $3.8 \%^{1}$ & $7.6 \%^{1}$ & $11.4 \%^{1}$ & $3.8 \%$ & $7.6 \%$ & SEM & Roughage (R) & $\mathrm{CaMg}\left(\mathrm{CO}_{3}\right)_{2}$ & $\mathrm{R} \times \mathrm{CaMg}\left(\mathrm{CO}_{3}\right)_{2}$ \\
\hline $\mathrm{Ca}$ & 36.2 & 44.0 & 46.5 & 47.6 & 41.9 & 3.8 & 0.33 & 0.29 & 0.05 \\
\hline $\mathrm{P}$ & 20.7 & 24.2 & 25.9 & 25.4 & 23.5 & 2.2 & 0.28 & 0.51 & 0.14 \\
\hline $\mathrm{Mg}$ & 21.6 & 24.4 & 23.7 & 23.7 & 21.4 & 2.1 & 0.82 & 0.60 & 0.15 \\
\hline $\mathrm{P}$ & 7.00 & 7.50 & 9.03 & 6.55 & 7.25 & 2.4 & 0.57 & 0.56 & 0.96 \\
\hline $\mathrm{Mg}$ & 13.6 & 15.4 & 18.7 & 14.0 & 17.4 & 4.2 & 0.43 & 0.95 & 0.82 \\
\hline \multicolumn{10}{|c|}{ Total tract digestion, $\%$} \\
\hline $\mathrm{Ca}$ & 9.4 & 18.1 & 32.4 & 40.2 & 19.7 & 20.3 & 0.80 & 0.53 & 0.44 \\
\hline $\mathrm{P}$ & 66.8 & 70.5 & 66.6 & 74.6 & 73.3 & 6.5 & 0.68 & 0.21 & 0.67 \\
\hline $\mathrm{Mg}$ & 35.7 & 35.5 & 24.9 & 39.0 & 25.0 & 16.2 & 0.71 & 0.99 & 0.64 \\
\hline
\end{tabular}

${ }^{1}$ Roughage equivalent from corn silage.

gestibility to increase with the addition of $\mathrm{CaMg}\left(\mathrm{CO}_{3}\right)_{2}$. In addition, there was a tendency for a roughage concentration $\times \mathrm{CaMg}\left(\mathrm{CO}_{3}\right)_{2}$ supplementation interaction for poststomach digestion (\% leaving the abomasum) of OM $(P=0.08)$ and $\operatorname{starch}(P=0.09)$. Poststomach digestion of $\mathrm{OM}$ and starch was greater when $3.8 \%$ roughage and $\mathrm{CaMg}\left(\mathrm{CO}_{3}\right)_{2}$ were fed and less when $7.6 \%$ roughage and $\mathrm{CaMg}\left(\mathrm{CO}_{3}\right)_{2}$ were fed compared with the same diets with no $\mathrm{CaMg}\left(\mathrm{CO}_{3}\right)_{2}$. Poststomach NDF digestion did not differ $(P \geq 0.17)$ among treatments. Total tract digestion of $\mathrm{OM}$ tended $(P<0.10)$ to decrease linearly and starch decreased linearly $(P$ $<0.01)$ with increasing roughage concentration. In addition, there was a tendency $(P=0.06)$ for a roughage concentration $\times \mathrm{CaMg}\left(\mathrm{CO}_{3}\right)_{2}$ interaction for total tract digestion of OM. Total tract OM digestion was greater when $7.6 \%$ roughage with no $\mathrm{CaMg}\left(\mathrm{CO}_{3}\right)_{2}$ was fed compared with $7.6 \%$ roughage with $\mathrm{CaMg}\left(\mathrm{CO}_{3}\right)_{2}$, whereas OM digestion was greater when $3.8 \%$ roughage and $\mathrm{CaMg}\left(\mathrm{CO}_{3}\right)_{2}$ were fed compared with $3.8 \%$ roughage and no $\mathrm{CaMg}\left(\mathrm{CO}_{3}\right)_{2}$.

There was a roughage concentration $\times \mathrm{CaMg}\left(\mathrm{CO}_{3}\right)_{2}$ interaction $(P=0.05)$ for Ca intake (Table 6). Calcium intake was greater when $3.8 \%$ roughage and $\mathrm{CaMg}\left(\mathrm{CO}_{3}\right)_{2}$ were fed and less when $7.6 \%$ roughage and $\mathrm{CaMg}\left(\mathrm{CO}_{3}\right)_{2}$ were fed compared with the same diets with no $\mathrm{CaMg}\left(\mathrm{CO}_{3}\right)_{2}$. Total tract digestibility of $\mathrm{Ca}$, $\mathrm{P}$, and $\mathrm{Mg}$ was not altered $(P>0.21)$ by dietary treatment.

Fluid dilution rate did not differ $(P \geq 0.24)$ among dietary treatments, but fluid flow out of the rumen was decreased $(P=0.03)$ with the addition of $\mathrm{CaMg}\left(\mathrm{CO}_{3}\right)_{2}$ (Table 7). There was also a tendency $(P=0.06)$ for a roughage concentration $\times \mathrm{CaMg}\left(\mathrm{CO}_{3}\right)_{2}$ interaction for fluid flow rate. Fluid flow rate was greater when $7.6 \%$ roughage with no $\mathrm{CaMg}\left(\mathrm{CO}_{3}\right)_{2}$ was fed compared with $7.6 \%$ roughage with $\mathrm{CaMg}\left(\mathrm{CO}_{3}\right)_{2}$, whereas fluid flow rate was greater when $3.8 \%$ roughage and no $\mathrm{CaMg}\left(\mathrm{CO}_{3}\right)_{2}$ were fed compared with $3.8 \%$ roughage with $\mathrm{CaMg}\left(\mathrm{CO}_{3}\right)_{2}$. Ruminal $\mathrm{pH}$ tended $(P=0.08)$ to increase with increasing roughage level. In addition, time spent below ruminal $\mathrm{pH}$ of 6.2 tended $(P=0.10)$ to decrease with increasing roughage concentration. Roughage concentration or $\mathrm{CaMg}\left(\mathrm{CO}_{3}\right)_{2}$ supplementation had no effect $(P \geq 0.10)$ on total VFA concentration or molar proportions of propionate, butyrate, valerate, isobutyrate, isovalerate, or ammonia. Molar proportion of acetate tended $(P=0.09)$ to increase with increasing roughage concentration.

\section{Exp. 3}

An interaction $(P=0.01)$ between alfalfa concentration and $\mathrm{CaMg}\left(\mathrm{CO}_{3}\right)_{2}$ inclusion was observed for $\mathrm{DMI} / \mathrm{meal}$ as steers consuming the $13.5 \%$ alfalfa, $1.0 \%$ $\mathrm{CaMg}\left(\mathrm{CO}_{3}\right)_{2}$ treatment had greater $\mathrm{DMI} /$ meal than those consuming either the $4.5 \%$ alfalfa, no $\mathrm{CaMg}\left(\mathrm{CO}_{3}\right)_{2}$ treatment or the $9.0 \%$ alfalfa, $1.0 \% \mathrm{CaMg}\left(\mathrm{CO}_{3}\right)_{2}$ treatment (Table 8). A similar interaction $(P=0.01)$ was observed for time spent eating per meal, because steers consuming the $13.5 \%$ alfalfa, $1.0 \% \mathrm{CaMg}\left(\mathrm{CO}_{3}\right)_{2}$ treatment and the $9.0 \%$ alfalfa, no $\mathrm{CaMg}\left(\mathrm{CO}_{3}\right)_{2}$ treatment spent more time eating per meal than steers consuming the $4.5 \%$ alfalfa, no $\mathrm{CaMg}\left(\mathrm{CO}_{3}\right)_{2}$ treatment. There were no dietary alfalfa concentration $\times \mathrm{CaMg}\left(\mathrm{CO}_{3}\right)_{2}$ inclusion interactions $(P \geq 0.12)$ for any other intake variable. Neither the main effect of dietary alfalfa concentration nor the main effect of $\mathrm{CaMg}\left(\mathrm{CO}_{3}\right)_{2}$ inclusion was significant $(P \geq 0.18)$ for any of the measured intake variables.

Due to an error in the sampling protocol, poststomach digestibility was not able to be measured in this experiment. However, the sampling error did not affect our measurement of total tract nutrient digestibility (Table 9$)$. There were no differences $(P \geq 0.48)$ observed for total tract $\mathrm{OM}$ digestibility due to $\mathrm{CaMg}\left(\mathrm{CO}_{3}\right)_{2}$ inclusion or a $\mathrm{CaMg}\left(\mathrm{CO}_{3}\right)_{2}$ inclusion $\times$ dietary alfalfa concentration interaction. Total tract $\mathrm{OM}$ digestibility decreased linearly $(P=0.01)$ with increasing dietary alfalfa concentrations. Total tract digestibilities of 
Table 7. Ruminal pH, VFA, and ammonia in steers fed increasing roughage with or without $\mathrm{CaMg}\left(\mathrm{CO}_{3}\right)_{2}(\operatorname{Exp}$. 2)

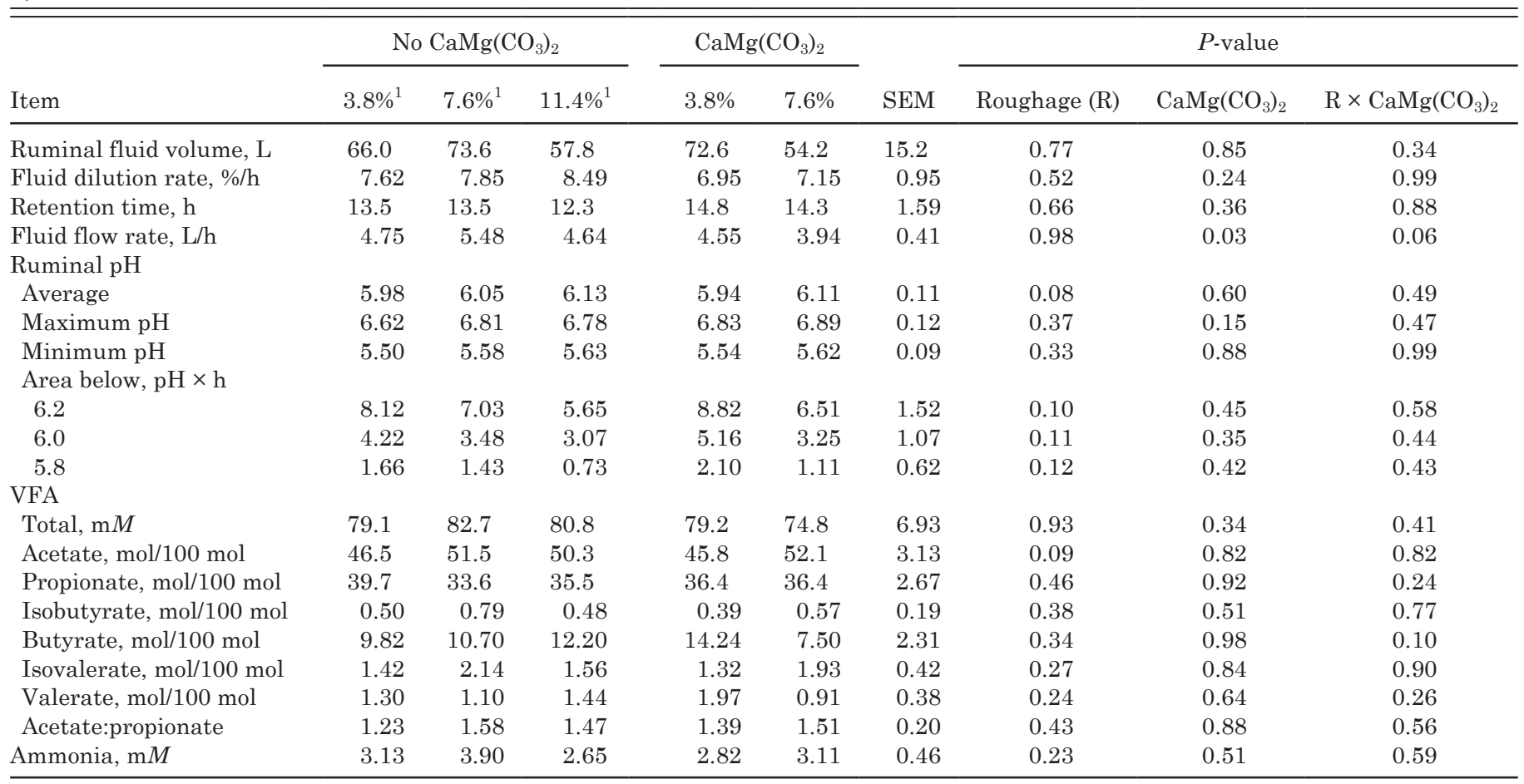

${ }^{1}$ Roughage equivalent from corn silage.

NDF, starch, and CP also decreased linearly $(P \leq 0.03)$ with increasing dietary alfalfa concentration and were not affected $(P \geq 0.10)$ by $\mathrm{CaMg}\left(\mathrm{CO}_{3}\right)_{2}$ inclusion or a $\mathrm{CaMg}\left(\mathrm{CO}_{3}\right)_{2}$ inclusion $\times$ dietary alfalfa concentration interaction. Total tract digestibilities of $\mathrm{Ca}, \mathrm{P}$, and $\mathrm{Mg}$ were not affected $(P \geq 0.20)$ by $\mathrm{CaMg}\left(\mathrm{CO}_{3}\right)_{2}$ inclusion, dietary alfalfa concentration, or a $\mathrm{CaMg}\left(\mathrm{CO}_{3}\right)_{2}$ inclusion $\times$ dietary alfalfa concentration interaction.

There were no effects $(P \geq 0.12)$ on ruminal fluid or solids dilution rates or ruminal $\mathrm{pH}$ due to either $\mathrm{CaMg}\left(\mathrm{CO}_{3}\right)_{2}$ inclusion or a $\mathrm{CaMg}\left(\mathrm{CO}_{3}\right)_{2} \times$ dietary alfalfa concentration interaction; therefore, all ruminal $\mathrm{pH}$ data are presented showing the main effects of dietary alfalfa concentration and $\mathrm{CaMg}\left(\mathrm{CO}_{3}\right)_{2}$ inclusion (Table 10). Average ruminal $\mathrm{pH}$ responded linearly $(P=0.01)$ to increasing dietary alfalfa concentration, with the lowest ruminal $\mathrm{pH}$ observed at the $4.5 \%$ dietary alfalfa concentration and the highest at the $13.5 \%$ dietary alfalfa concentration. Maximum $(P=0.09)$ and minimum $(P=0.05)$ ruminal $\mathrm{pH}$ exhibited a response similar to that observed with average $\mathrm{pH}$. The difference between the maximum and minimum $\mathrm{pH}(\mathrm{pH}$ range; $P \geq 0.34$ ) was fairly constant across dietary alfalfa concentration, as was $\mathrm{pH}$ variance $(P \geq 0.27)$. A linear response $(P \leq 0.05)$ due to dietary alfalfa concentration was observed for time below $\mathrm{pH} 5.6$ and time below $\mathrm{pH} 5.3$. For both variables, the time below the stated threshold was greatest when steers consumed the $4.5 \%$ dietary alfalfa treatments. Time spent below $\mathrm{pH} 5.6$ was decreased 16 and $23 \%$ when steers consumed diets containing 9.0 or $13.5 \%$ alfalfa, respectively. Area below $\mathrm{pH} 5.6$ responded $(P=0.03)$ similarly to time below $\mathrm{pH}$

Table 8. Effects of alfalfa hay concentration and $\mathrm{CaMg}\left(\mathrm{CO}_{3}\right)_{2}$ inclusion on intake and intake variables (Exp. 3)

\begin{tabular}{|c|c|c|c|c|c|c|c|c|c|c|}
\hline \multirow[b]{2}{*}{ Item } & \multicolumn{3}{|c|}{ No $\mathrm{CaMg}\left(\mathrm{CO}_{3}\right)_{2}$} & \multicolumn{3}{|c|}{$1.0 \% \mathrm{CaMg}\left(\mathrm{CO}_{3}\right)_{2}$} & \multirow[b]{2}{*}{ SEM } & \multicolumn{3}{|c|}{$P$-value } \\
\hline & $4.5 \%^{1}$ & $9.0 \%^{1}$ & $13.5 \%^{1}$ & $4.5 \%$ & $9.0 \%$ & $13.5 \%$ & & Alfalfa & $\mathrm{CaMg}\left(\mathrm{CO}_{3}\right)_{2}$ & $\begin{array}{c}\text { Alfalfa } \times \\
\mathrm{CaMg}\left(\mathrm{CO}_{3}\right)_{2}\end{array}$ \\
\hline \multicolumn{11}{|l|}{ DMI } \\
\hline $\mathrm{kg} / \mathrm{d}$ & 6.36 & 6.99 & 6.76 & 6.76 & 6.36 & 6.86 & 0.36 & 0.55 & 0.94 & 0.12 \\
\hline $\mathrm{kg} / \mathrm{meal}$ & $1.03^{\mathrm{c}}$ & $1.24^{\mathrm{bc}}$ & $1.15^{\mathrm{bc}}$ & $1.18^{\mathrm{bc}}$ & $0.97^{\mathrm{c}}$ & $1.29^{\mathrm{b}}$ & 0.10 & 0.21 & 0.95 & 0.01 \\
\hline Meals/d & 6.19 & 5.62 & 5.89 & 5.75 & 6.57 & 5.32 & 0.46 & 0.18 & 0.99 & 0.13 \\
\hline \multicolumn{11}{|l|}{ Time eating } \\
\hline $\mathrm{min} / \mathrm{d}$ & 503 & 603 & 537 & 572 & 564 & 557 & 42 & 0.23 & 0.61 & 0.12 \\
\hline $\mathrm{min} / \mathrm{meal}$ & $81.2^{\mathrm{d}}$ & $107.3^{\mathrm{b}}$ & $91.1^{\mathrm{bcd}}$ & $99.4^{\mathrm{bc}}$ & $85.8^{\mathrm{cd}}$ & $104.7^{\mathrm{b}}$ & 7.7 & 0.42 & 0.48 & 0.01 \\
\hline Rate of intake, $\% / h$ & 17.2 & 18.0 & 16.8 & 17.1 & 15.1 & 16.9 & 1.0 & 0.82 & 0.19 & 0.19 \\
\hline
\end{tabular}

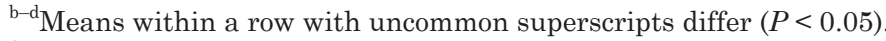

${ }^{1}$ Alfalfa hay.
} 
Table 9. Effects of alfalfa hay concentration and $\mathrm{CaMg}\left(\mathrm{CO}_{3}\right)_{2}$ inclusion on nutrient intake, excretion, and total tract digestibility (Exp. 3)

\begin{tabular}{|c|c|c|c|c|c|c|c|c|c|c|c|}
\hline \multirow[b]{2}{*}{ Item } & \multicolumn{3}{|c|}{ No $\mathrm{CaMg}\left(\mathrm{CO}_{3}\right)_{2}$} & \multicolumn{3}{|c|}{$1.0 \% \mathrm{CaMg}\left(\mathrm{CO}_{3}\right)_{2}$} & \multirow[b]{2}{*}{ SEM } & \multicolumn{4}{|c|}{$P$-value } \\
\hline & $4.5 \%^{1}$ & $9.0 \%^{1}$ & $13.5 \%^{1}$ & $4.5 \%$ & $9.0 \%$ & $13.5 \%$ & & $\begin{array}{l}\text { Alfalfa- } \\
\text { linear }\end{array}$ & $\begin{array}{l}\text { Alfalfa- } \\
\text { quadratic }\end{array}$ & $\mathrm{CaMg}\left(\mathrm{CO}_{3}\right)_{2}$ & $\begin{array}{c}\text { Alfalfa } \times \\
\mathrm{CaMg}\left(\mathrm{CO}_{3}\right)_{2}\end{array}$ \\
\hline \multicolumn{12}{|l|}{$\mathrm{OM}$} \\
\hline Intake, kg/d & 6.24 & 6.81 & 6.36 & 6.36 & 5.97 & 6.59 & 0.39 & 0.42 & 0.99 & 0.35 & 0.03 \\
\hline Excretion, kg/d & 0.92 & 1.12 & 1.12 & 0.88 & 0.83 & 1.24 & 0.11 & 0.01 & 0.39 & 0.36 & 0.08 \\
\hline Intake, $\mathrm{kg} / \mathrm{d}$ & 0.861 & 1.070 & 1.168 & 0.997 & 0.952 & 1.267 & 0.062 & $<0.001$ & 0.09 & 0.25 & 0.01 \\
\hline Excretion, kg/d & 0.211 & 0.289 & 0.357 & 0.215 & 0.256 & 0.370 & 0.033 & $<0.001$ & 0.47 & 0.80 & 0.62 \\
\hline Digestibility, \% & 75.4 & 73.1 & 68.8 & 78.3 & 73.1 & 70.9 & 2.7 & 0.01 & 0.90 & 0.39 & 0.80 \\
\hline \multicolumn{12}{|l|}{ Starch } \\
\hline Intake, kg/d & 3.80 & 3.86 & 3.41 & 4.05 & 3.54 & 3.36 & 0.22 & 0.002 & 0.63 & 0.75 & 0.19 \\
\hline Excretion, kg/d & 0.145 & 0.180 & 0.161 & 0.149 & 0.131 & 0.188 & 0.024 & 0.22 & 0.24 & 0.38 & 0.05 \\
\hline \multicolumn{12}{|l|}{$\mathrm{Ca}$} \\
\hline Intake, $\mathrm{g} / \mathrm{d}$ & 53.8 & 55.6 & 55.8 & 53.1 & 49.4 & 54.3 & 3.2 & 0.39 & 0.27 & 0.08 & 0.28 \\
\hline Excretion, g/d & 27.0 & 32.4 & 35.4 & 29.2 & 23.9 & 30.5 & 3.5 & 0.12 & 0.39 & 0.16 & 0.22 \\
\hline Digestibility, \% & 50.1 & 42.6 & 38.1 & 44.4 & 51.2 & 44.2 & 5.0 & 0.21 & 0.52 & 0.45 & 0.29 \\
\hline \multicolumn{12}{|l|}{$\mathrm{P}$} \\
\hline Intake, $\mathrm{g} / \mathrm{d}$ & 18.7 & 20.8 & 20.2 & 19.8 & 18.8 & 19.9 & 1.2 & 0.36 & 0.85 & 0.61 & 0.19 \\
\hline Excretion, g/d & 9.3 & 10.2 & 8.3 & 8.2 & 9.0 & 10.3 & 1.6 & 0.67 & 0.61 & 0.92 & 0.38 \\
\hline Digestibility, \% & 51.2 & 51.5 & 58.7 & 58.2 & 51.4 & 49.3 & 6.3 & 0.89 & 0.50 & 0.84 & 0.29 \\
\hline \multicolumn{12}{|l|}{$\mathrm{Mg}$} \\
\hline Intake, g/d & 16.5 & 18.2 & 18.1 & 18.0 & 16.8 & 18.4 & 1.0 & 0.18 & 0.72 & 0.83 & 0.14 \\
\hline Excretion, g/d & 9.0 & 11.3 & 9.9 & 10.4 & 8.8 & 10.7 & 1.0 & 0.49 & 0.96 & 0.90 & 0.10 \\
\hline Digestibility, \% & 45.7 & 38.4 & 47.8 & 42.5 & 46.8 & 41.2 & 4.4 & 0.92 & 0.64 & 0.90 & 0.20 \\
\hline
\end{tabular}

${ }^{1}$ Alfalfa hay.

5.6 , whereas area below pH 5.3 was not affected $(P \geq$ 0.12 ) by dietary alfalfa concentration.

Total VFA averaged $101.5 \pm 9.2 \mathrm{~m} M$ across all treatments (Table 10). Dietary inclusion of $\mathrm{CaMg}\left(\mathrm{CO}_{3}\right)_{2}$ did not affect $(P \geq 0.21)$ any measured VFA variable. Molar proportion of acetate increased linearly $(P=0.002)$ and tended ( $P=0.07)$ to respond quadratically to increasing dietary alfalfa concentration. A quadratic response $(P=0.01)$ due to dietary alfalfa concentration was observed for propionate molar proportion, with the greatest propionate molar proportion observed when steers consumed the $9.0 \%$ dietary alfalfa treatments. This quadratic response was also present for butyrate molar proportion $(P=0.04)$ and the acetate:propionate ratio $(P=0.03)$, with the lowest response observed with the $9.0 \%$ dietary alfalfa concentration. Ruminal ammonia concentration and purine derivative:creatinine ratios were not affected $(P \geq 0.34)$ by dietary alfalfa concentration, $\mathrm{CaMg}\left(\mathrm{CO}_{3}\right)_{2}$ inclusion, or their interaction.

\section{DISCUSSION}

Ruminal buffers (e.g., sodium bicarbonate) are thought to actively buffer ruminal fluid and increase ruminal $\mathrm{pH}$ through the increase of bicarbonate in ruminal fluid (Le Ruyet and Tucker, 1992). However, Russell and Rychlik (2001) suggested that the effect of sodium bicarbonate is greatest when the rumen is moderately acidic, as with dairy cow rations, and may not be as effective in high-concentrate feeding situations in which ruminal $\mathrm{pH}$ is often below $\mathrm{pH}$ 6.0. Alkalizers, such as limestone and $\mathrm{MgO}$, were suggested to be more effective at low $\mathrm{pH}$ than bicarbonate (Russell and Rychlik, 2001). The ruminal alkalizer used in the current set of experiments was $\mathrm{CaMg}\left(\mathrm{CO}_{3}\right)_{2}$, which contains approximately $12 \% \mathrm{Mg}$ and $21 \% \mathrm{Ca}$. Tissera et al. (1988) reported that the total acid-consuming capacity of dolomitic limestones ranged from 20.5 to 22.6 $\mathrm{mEq}$ of $\mathrm{H}^{+} / \mathrm{g}$, which is similar to unpublished data for the $\mathrm{CaMg}\left(\mathrm{CO}_{3}\right)_{2}$ used in the present experiment (20.0 to $21.3 \mathrm{mEq}$ of $\mathrm{H}^{+} / \mathrm{g}$; MIN-AD Inc.).

Results from experiments that have evaluated the efficacy of buffers and alkalizers in cattle fed highconcentrate diets have been inconsistent. Zinn and Borques (1993) conducted 2 feeding experiments with Angus $\times$ Brahman and Holstein steers and reported no effects on DMI, ADG, or G:F when $0.75 \%$ sodium bicarbonate was added to steam-flaked corn-based diets. In an earlier study, Zinn (1991) reported a 5.9\% increase in $\mathrm{ADG}$ and a $4.6 \%$ increase in $\mathrm{DMI}$ when $0.75 \%$ sodium bicarbonate was added to finishing diets contain- 
Table 10. Effects of alfalfa hay concentration and $\mathrm{CaMg}\left(\mathrm{CO}_{3}\right)_{2}$ inclusion on ruminal measurements and urinary purine derivative:creatinine ratio (Exp. 3)

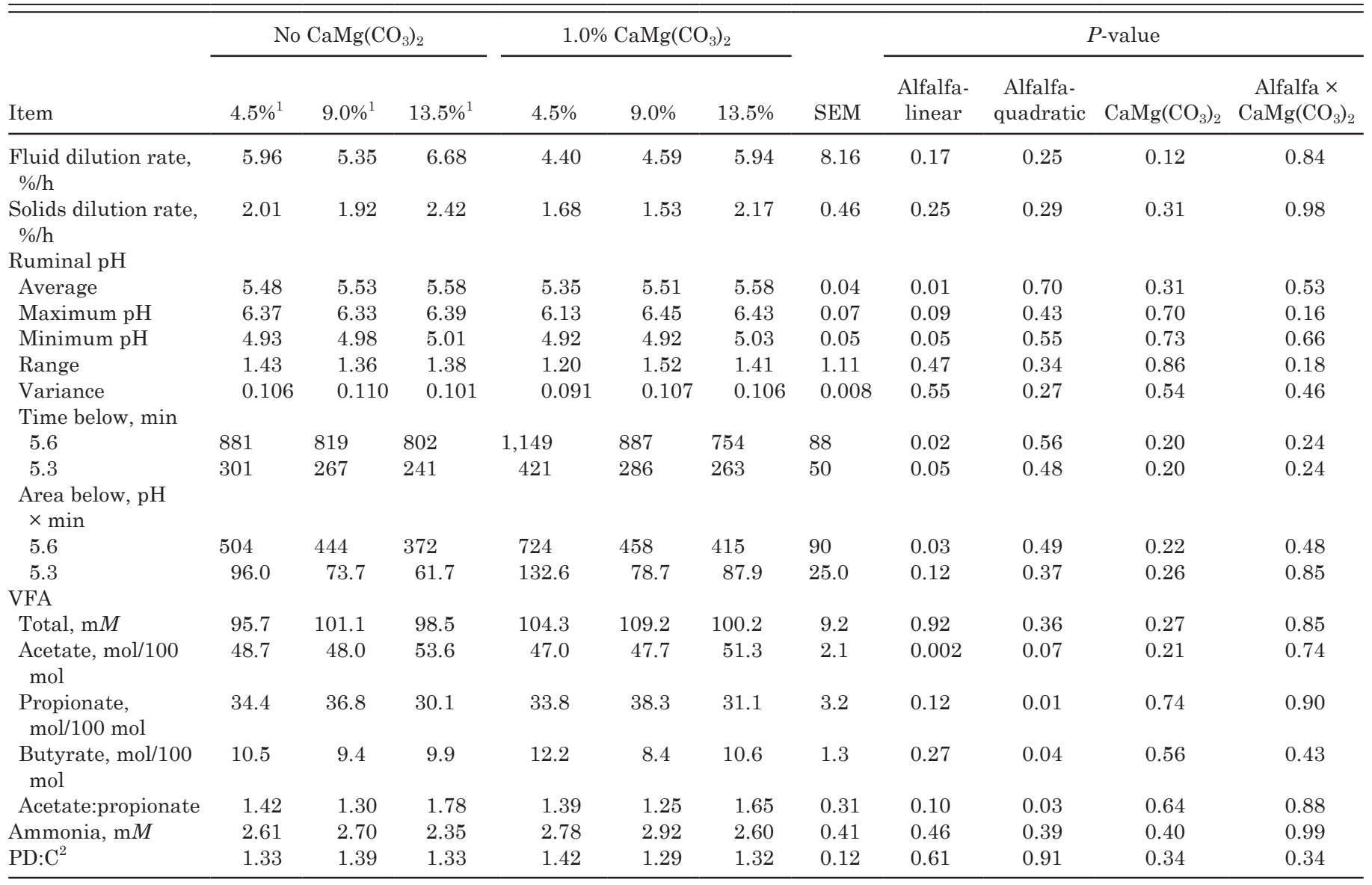

${ }^{1}$ Alfalfa hay.

${ }^{2}$ Purine derivative:creatinine ratio, $\mathrm{mol} / \mathrm{mol}$.

ing high concentrations of either steam-flaked corn or steam-flaked sorghum. Thomas and Hall (1984) fed diets containing $61.6 \%$ cracked corn and $20 \%$ cottonseed hulls and observed a 14\% increase in ADG and an 18\% improvement in G:F when tetrasodium pyrophosphate was added to the diets. Adding sodium bicarbonate to the basal diets resulted in a $13.5 \%$ improvement in G:F (Thomas and Hall, 1984). Russell et al. (1980) reported no differences in DMI, $\mathrm{ADG}$, or $\mathrm{G}: \mathrm{F}$ when either $0.9 \%$ sodium bicarbonate or $1.8 \%$ limestone was supplemented to corn-based diets containing greater than $90 \%$ concentrate. Adding either sodium bentonite or sodium bicarbonate to diets containing $92 \%$ ground corn-based concentrate produced no effects on DMI, ADG, or G:F (Dunn et al., 1979). Similarly, Stroud et al. (1985) observed no effects on DMI, ADG, and G:F when sodium bicarbonate was added to a cracked corn-based feedlot steer diet. In Exp. 1, we observed no effect of feeding $\mathrm{CaMg}\left(\mathrm{CO}_{3}\right)_{2}$ on DMI, ADG, or G:F.

In Exp. 3, $\mathrm{CaMg}\left(\mathrm{CO}_{3}\right)_{2}$ had no effect on feed intake behavior, but there were roughage $\times \mathrm{CaMg}\left(\mathrm{CO}_{3}\right)_{2}$ interactions for $\mathrm{DMI} / \mathrm{meal}$ and time eating/meal. Steers consuming the $4.5 \%$ roughage, no $\mathrm{CaMg}\left(\mathrm{CO}_{3}\right)_{2}$ treatment could have experienced a digestive disturbance that may have affected the feed intake behavior of those steers. However, this observation was not substantiated by the ruminal $\mathrm{pH}$ data.

We did not observe an increase in ruminal fluid dilution rate with $\mathrm{CaMg}\left(\mathrm{CO}_{3}\right)_{2}$ inclusion in either metabolism experiment (Exp. 2 and 3). An increase in ruminal fluid dilution rate would allow less digestion of fermentable carbohydrates such as starch, leading to less organic acid production and less risk of acidosis (Russell and Chow, 1993). Similarly, Haaland and Tyrell (1982) reported no response in ruminal fluid or solids dilution rates when either limestone or sodium bicarbonate was added to corn-based diets fed to cattle. Peirce et al. (1983) reported a decrease in ruminal dilution rate when $0.5 \% \mathrm{MgO}$ was added to diets based on whole corn. In contrast, Rogers et al. (1979) continuously infused $0.72 \mathrm{~kg} / \mathrm{d}$ of sodium bicarbonate into the rumen and reported a $30 \%$ increase in daily water intake compared with no sodium bicarbonate infusion in Holstein steers fed a high-roughage diet. The water intake response in the Rogers et al. (1979) experiment was attributed to the sodium content of the buffer resulting in increased ruminal osmolality. Rogers et al. (1979) noted that the increase in water intake did not totally account for the increase in ruminal liquid dilution rate, and the authors suggested that transruminal 
water influx must have occurred to account for the increase. Differences in response among experiments are most likely due in part to differences in basal diet fed, type and amount of buffer or alkalizer fed, and ability of buffer or alkalizer to neutralize acid.

Stomach, poststomach, and total tract nutrient digestibilities were not influenced by addition of $\mathrm{CaMg}\left(\mathrm{CO}_{3}\right)_{2}$ in either Exp. 2 or 3. This agrees with data from Zinn and Borques (1993) showing no effect of sodium bicarbonate on nutrient digestion. Stroud et al. (1985) reported an increase in total tract DM, NDF, starch, and $\mathrm{N}$ digestion when $1 \%$ sodium bicarbonate was added to cracked corn-based diets. Zinn (1991) reported an increase in total tract ADF digestion with the inclusion of sodium bicarbonate in steam-flaked corn and sorghum diets with no effects on any other digestion measure.

Very little data are available comparing mineral availability responses when different sources of $\mathrm{Ca}$ or $\mathrm{Mg}$ are supplied to cattle. In the present experiments, diets were balanced for $\mathrm{Ca}$ and $\mathrm{Mg}$ with these minerals being supplied by limestone and $\mathrm{MgO}$ in the diets without $\mathrm{CaMg}\left(\mathrm{CO}_{3}\right)_{2}$. In the $\mathrm{CaMg}\left(\mathrm{CO}_{3}\right)_{2}$-containing diets, $\mathrm{MgO}$ was completely replaced and limestone was partially replaced. Gerken and Fontenot (1967) reported dietary $\mathrm{Mg}$ availability of 14.3 and $51.1 \%$ when $\mathrm{Mg}$ was supplemented to beef steers as dolomitic limestone and $\mathrm{MgO}$, respectively. These researchers also reported a numeric decline in $\mathrm{Ca}$ absorption with dolomitic limestone compared with $\mathrm{MgO}$ with no differences in $\mathrm{P}$ absorption. Moore et al. (1971) also reported low Mg absorptions with dolomitic limestone in steers, because $\mathrm{Mg}$ absorption measured 45.6, 43.5, and $32.5 \%$ of $\mathrm{Mg}$ intake when $\mathrm{Mg}$ was supplemented as $\mathrm{MgO}, \mathrm{MgCO}_{3}$, or dolomitic limestone. These researchers did not observe differences in $\mathrm{Ca}$ or $\mathrm{P}$ absorption. In general, mineral digestibility values reported in the literature have been highly variable both within and among experiments.

As with other measures, the response of ruminal $\mathrm{pH}$ to buffers has been variable. Zinn (1991) reported an increase in average ruminal $\mathrm{pH}$ from 5.87 to 6.23 when sodium bicarbonate was included in steam-flaked grain diets. Farran et al. (2003) observed an increase in ruminal $\mathrm{pH}$ and a decrease in time spent below $\mathrm{pH} 5.6$ when $1.25 \%$ sodium bicarbonate was added to heifer diets containing $92.5 \%$ concentrate. However, sodium bicarbonate supplementation decreased DMI in the Farran et al. (2003) experiment, which may be the explanation for the increase in ruminal $\mathrm{pH}$. Increases in ruminal $\mathrm{pH}$ have also been reported as a response to buffer addition to high-concentrate diets by Stroud et al. (1985) and Boerner et al. (1987). In the present experiment, $\mathrm{CaMg}\left(\mathrm{CO}_{3}\right)_{2}$ inclusion had no effect on any ruminal $\mathrm{pH}$ variables in Exp. 2 or 3 . This agrees with previous research (Haaland and Tyrell, 1982; Peirce et al., 1983) that reported no effect on ruminal $\mathrm{pH}$ due to dietary buffer inclusion.

We did not observe any effects on total VFA or any individual VFA due to $\mathrm{CaMg}\left(\mathrm{CO}_{3}\right)_{2}$ inclusion. The lack of response in VFA is in agreement with the lack of responses in fluid dilution rate, nutrient digestion, DMI, and ruminal pH. Other researchers (Russell et al., 1980; Haaland and Tyrell, 1982; Zinn and Borques, 1993) have also reported a lack of response in VFA measurements due to dietary addition of a ruminal buffer or alkalizer. However, Boerner et al. (1987) found an increase in propionate when $1 \%$ sodium bicarbonate or sodium sesquicarbonate was added to high-concentrate diets. Zinn (1991) reported a decrease in ruminal propionate from 37 to $30 \mathrm{~mol} / 100 \mathrm{~mol}$ when $0.75 \%$ sodium bicarbonate was added to steam-flaked grain diets. This accompanied an increase in ruminal $\mathrm{pH}$ and an increase in DMI.

In contrast with the lack of effects observed with the addition of $\mathrm{CaMg}\left(\mathrm{CO}_{3}\right)_{2}$, we did observe significant effects due to increasing dietary roughage in Exp. 2 and 3. Roughage is provided at low concentrations in nearly all beef cattle finishing rations, with concentrations ranging from 4.5 to $13.5 \%$ of diet DM (Galyean and Gleghorn, 2001). A common observation with previous research on dietary roughage concentration is decreased DMI and ADG when lesser amounts of dietary roughage are fed, with variable responses on $\mathrm{G}: \mathrm{F}$ (Stock et al., 1990; Shain et al., 1999; Farran et al., 2006). These responses are most likely due to a greater incidence of ruminal acidosis with decreased dietary roughage concentration. Galyean and Defoor (2003) stated that small changes in the dietary concentration of bulky roughage and changing from less fibrous to more fibrous sources of roughage typically increase DMI by feedlot cattle. Kreikemeier et al. (1990) observed that the percentage of NDF in ruminal digesta increased linearly with increasing dietary roughage. Shain et al. (1999) reported an increase in ruminal $\mathrm{pH}$, ruminal acetate concentration, and acetate:propionate ratio coupled with an increase in time spent eating, chewing, and ruminating when steers were fed diets with wheat straw compared with diets containing no roughage. They attributed the response in ruminal $\mathrm{pH}$ to the buffering effect of increased saliva output and increased rumination due to the increase in time spent chewing with wheat straw addition to the diet. Ruminal VFA results from Exp. 2 and 3 reflect the findings of Shain et al. (1999), with trends detected in Exp. 2 for an increase in total ruminal VFA concentration and acetate molar proportion with increased dietary roughage, and a linear increase in acetate molar proportion with increasing dietary roughage concentration in Exp. 3 .

A tendency for an increase in ruminal $\mathrm{pH}$ due to dietary roughage concentration was present in Exp. 2, and in Exp. 3, the increase was linear with a $0.17 \mathrm{pH}$ unit increase when the dietary roughage concentration increased from 4.5 to $13.5 \%$. Owens et al. (1998) noted that an increase in dietary roughage will result in an increase in chewing time, which will decrease the size of grain particles. However, the potential increase in ruminal organic acid production and subsequent reduction in ruminal $\mathrm{pH}$ with decreased grain particle size 
is offset by an increase in saliva production from increased chewing (Owens et al., 1998). Increased saliva production would also be expected to increase ruminal fluid dilution rate (Russell and Chow, 1993); however, this response was not significant in either Exp. 2 or Exp. 3. Shain et al. (1999) reported no differences in ruminal passage rate of liquid, corn, or forage when $10 \%$ alfalfa hay, $5.6 \%$ wheat straw, or $5.4 \%$ corn cobs was added to dry-rolled, corn-based diets with similar dietary NDF. Cole et al. (1976) noted that dietary roughage addition had no effect on ruminal $\mathrm{pH}$ or total VFA concentration, whereas Zinn et al. (1994) reported that increasing dietary roughage concentration increased ruminal $\mathrm{pH}$ and decreased total VFA. Similarly, Kreikemeier et al. (1990) reported an increase in total VFA concentrations with increased dietary roughage concentration. Similar to the present results, White and Reynolds (1969) and Calderon-Cortes and Zinn (1996) observed that ruminal $\mathrm{pH}$ increased with increasing dietary roughage concentration. In general, our results are consistent with the previous literature and suggest that increasing dietary roughage concentration increases ruminal $\mathrm{pH}$.

In both metabolism experiments, linear decreases in total tract $\mathrm{OM}$ and starch digestibility with increasing dietary roughage concentration were observed. Similar to what we observed in Exp. 2, Calderon-Cortes and Zinn (1996) observed that dietary roughage concentration did not affect ruminal digestibility of OM, $\mathrm{ADF}$, feed-N, starch, or microbial efficiency. Other experiments (Zinn, 1986; Zinn et al., 1994) have reported similar results. In contrast, Cole et al. (1976) noted that cellulose digestion increased with increasing dietary roughage concentration. In general, it appears that dietary roughage concentration has minimal effects on ruminal digestion of nutrients in cattle fed high-concentrate diets.

Inclusion of $\mathrm{CaMg}\left(\mathrm{CO}_{3}\right)_{2}$ in high-concentrate diets to completely replace $\mathrm{MgO}$ and partially replace limestone has little effect on growth performance, carcass characteristics, feed intake behavior, ruminal kinetics, and nutrient digestibility. An increase in dietary roughage allows for greater ruminal $\mathrm{pH}$ and may act to prevent digestive disturbances, such as ruminal acidosis. There were no differences in site or extent of mineral digestion when $\mathrm{CaMg}\left(\mathrm{CO}_{3}\right)_{2}$ was supplemented to high-concentrate diets, suggesting it can be used effectively as a source of calcium and magnesium in diets fed to finishing feedlot cattle.

\section{LITERATURE CITED}

AOAC. 1997. Official Methods of Analysis. 16th ed. Assoc. Off. Anal. Chem., Arlington, VA.

Bock, B. J., D. L. Harmon, R. T. Brandt Jr, and J. E. Schneider. 1991. Fat source and calcium level effects on finishing steer performance, digestion, and metabolism. J. Anim. Sci. 69:22112224.

Boerner, B. J., F. M. Byers, G. T. Schelling, C. E. Coppock, and L. W. Greene. 1987. Trona and sodium bicarbonate in beef cattle diets: Effects on $\mathrm{pH}$ and volatile fatty acid concentrations. J. Anim. Sci. 65:309-316.

Broderick, G. A., and J. H. Kang. 1980. Automated simultaneous determination of ammonia and total amino acids in ruminal fluid and in vitro media. J. Dairy Sci. 63:64-75.

Calderon-Cortes, J. F., and R. A. Zinn. 1996. Influence of dietary forage coarseness of grind on growth performance and digestive function in feedlot steers. J. Anim. Sci. 74:2310-2316.

Cole, N. A., R. R. Johnson, and F. N. Owens. 1976. Influence of roughage level on the site and extent of digestion of whole shelled corn by beef steers. J. Anim. Sci. 43:483-489.

Cooper, R. J., T. J. Klopfenstein, R. A. Stock, C. T. Milton, D. W. Herold, and J. C. Parrott. 1999. Effects of imposed feed intake variation on acidosis and performance of finishing steers. J. Anim. Sci. 77:1093-1099.

Dunn, B. H., R. J. Emerick, and L. B. Embry. 1979. Sodium bentonite and sodium bicarbonate in high-concentrate diets for lambs and steers. J. Anim. Sci. 48:764-769.

Ellis, W. C., and D. E. Beever. 1984 Methods for binding rare earths to specific feed particles. Pages 154-165 in Techniques in Particle Size Analysis of Feed and Digesta in Ruminants. P. M. Kennedy, ed. Occas. Publ. No. 1. Can. Soc. Anim. Sci., Edmonton, Alberta, Canada.

Erickson, G. E., C. T. Milton, K. C. Fanning, R. J. Cooper, R. S. Swingle, J. C. Parrott, G. Vogel, and T. J. Klopfenstein. 2003. Interaction between bunk management and monensin concentration on finishing performance, feeding behavior, and ruminal metabolism during an acidosis challenge with feedlot cattle. J. Anim. Sci. 81:2869-2879.

Farran, T. B., G. E. Erickson, and T. J. Klopfenstein. 2003. Evaluation of buffering agents in feedlot diets for cattle. Nebr. Beef Cattle Rep. MP 80A:35-38.

Farran, T. B., G. E. Erickson, T. J. Klopfenstein, C. N. Macken, and R. U. Lindquist. 2006. Wet corn gluten feed and alfalfa hay levels in dry-rolled corn finishing diets: Effects on finishing performance and feedlot nitrogen mass balance. J. Anim. Sci. 84:1205-1214.

Galyean, M. L., and P. J. Defoor. 2003. Effects of roughage source and level on intake by feedlot cattle. J. Anim. Sci. 81(E. Suppl. 2):E8-E16.

Galyean, M. L., and J. F. Gleghorn. 2001. Summary of the 2000 Texas Tech University Nutritionist Survey. Burnett Center Internet Prog. Rep. No.12. http://www.afs.ttu.edu/burnett_center/ progress_reports/bc12.pdf Accessed Sep. 26, 2003.

Gerken, H. J. Jr, and J. P. Fontenot. 1967. Availability and utilization of magnesium from dolomitic limestone and magnesium oxide in steers. J. Anim. Sci. 26:1404-1408.

Goetsch, A. L., and M. L. Galyean. 1983. Influence of feeding frequency on passage of fluid and particulate markers in steers fed a concentrate diet. Can. J. Anim. Sci. 63:727-730.

Grovum, W. L., and V. J. Williams. 1973. Passage of marker through the alimentary tract and the biological relevance of rate-constants derived from the changes in concentration of marker in faeces. Br. J. Nutr. 30:313-329.

Haaland, G. L., and H. F. Tyrell. 1982. Effects of limestone and sodium bicarbonate buffers on rumen measurements and rate of passage in cattle. J. Anim. Sci. 55:935-942.

Hannah, S. M., R. C. Cochran, E. S. Vanzant, and D. L. Harmon. 1991. Influence of protein supplementation on site and extent of digestion, forage intake, and nutrient flow characteristics in steers consuming dormant bluestem-range forage. J. Anim. Sci. 69:2624-2633.

Kreikemeier, K. K., D. L. Harmon, R. T. Brandt Jr, T. G. Nagaraja, and R. C. Cochran. 1990. Steam-rolled wheat diets for finishing cattle: Effects of dietary roughage and feed intake on finishing steer performance and ruminal metabolism. J. Anim. Sci. 68:2130-2141.

Le Ruyet, P., and W. B. Tucker. 1992. Ruminal buffers: Temporal effects on buffering capacity and $\mathrm{pH}$ of ruminal fluid from cows fed a high concentrate diet. J. Dairy Sci. 75:1069-1077. 
Littell, R. C., G. A. Milliken, W. W. Stroup, and R. D. Stroup. 2000. Analysis of repeated measures data. Pages 103-105 in SAS System for Mixed Models. SAS Insitute Inc., Cary, NC.

Loerch, S. C. 1991. Efficacy of plastic pot scrubbers as a replacement for roughage in high-concentrate cattle diets. J. Anim. Sci. 69:2321-2328.

Merchen, N. R. 1988. Digestion, absorption and excretion in ruminants. Pages 172-201 in The Ruminant Animal: Digestive Physiology and Nutrition. D. C. Church, ed. Prentice Hall, Englewood Cliffs, NJ.

Moore, W. F., J. P. Fontenot, and R. E. Tucker. 1971. Relative effects of different supplemental magnesium sources on apparent digestibility in steers. J. Anim. Sci. 33:502-506.

NRC. 1996. Nutrient Requirements of Beef Cattle. 7th ed. Natl. Acad. Press, Washington, DC.

Owens, F. N., D. S. Secrist, W. J. Hill, and D. R. Gill. 1998. Acidosis in cattle: A review. J. Anim. Sci. 76:275-286.

Peirce, S. B., L. D. Muller, and H. W. Harpster. 1983. Influence of sodium bicarbonate and magnesium oxide on digestion and metabolism in yearling beef steers abruptly changed from high forage to high energy diets. J. Anim. Sci. 57:1561-1567.

Raun, N. S., and W. Burroughs. 1962. Suction strainer technique in obtaining rumen fluid samples from intact lambs. J. Anim. Sci. 21:454-457.

Rogers, J. A., B. C. Marks, C. L. Davis, and J. H. Clark. 1979. Alteration of rumen fermentation in steers by increasing rumen fluid dilution rate with mineral salts. J. Dairy Sci. 62:1599-1605.

Russell, J. B., and J. M. Chow. 1993. Another theory for the action of ruminal buffer salts: Decreased starch fermentation and propionate production. J. Dairy Sci. 76:826-830.

Russell, J. B., and J. L. Rychlik. 2001. Factors that alter rumen microbial ecology. Science 292:1119-1122.

Russell, J. R., A. W. Young, and N. A. Jorgensen. 1980. Effect of sodium bicarbonate and limestone additions to high grain diets on feedlot performance and ruminal and fecal parameters in finishing steers. J. Anim. Sci. 51:996-1002.

Shain, D. H., R. A. Stock, T. J. Klopfenstein, and D. W. Herold. 1999. The effect of forage source and particle size on finishing yearling steer performance and ruminal metabolism. J. Anim. Sci. 77:1082-1092.

Shingfield, K. J., and N. W. Offer. 1998. Evaluation of the spot urine sampling technique to assess urinary purine derivative excretion in lactating dairy cows. Anim. Sci. 66:557-568.

Shingfield, K. J., and N. W. Offer. 1999. Simultaneous determination of purine metabolites, creatinine, and pseudouridine in ruminant urine by reverse-phase high-performance liquid chromatography. J. Chromatogr. B Analyt. Technol. Biomed. Life Sci. 723:81-94.

Sindt, M. H., R. A. Stock, T. J. Klopfenstein, and D. H. Shain. 1993. Effect of protein source and grain type on finishing calf performance and ruminal metabolism. J. Anim. Sci. 71:1047-1056.
Stock, R. A., M. H. Sindt, J. C. Parrott, and F. K. Goedeken. 1990. Effects of grain type, roughage level, and monensin level on finishing cattle performance. J. Anim. Sci. 68:3441-3455.

Stroud, T. E., J. E. Williams, D. R. Ledoux, and J. A. Paterson. 1985. The influence of sodium bicarbonate and dehydrated alfalfa as buffers on steer performance and ruminal characteristics. J. Anim. Sci. 60:551-559.

Thomas, E. E., and M. W. Hall. 1984. Effect of sodium bicarbonate and tetrasodium pyrophosphate upon utilization of concentrateand roughage-based cattle diets: Cattle studies. J. Anim. Sci. 59:1309-1319.

Tissera, G. H., J. H. Vandersall, and R. A. Erdman. 1988. Effects of limestone on starch digestion in Holstein steers. J. Dairy Sci. 71:754-761.

Uden, P., P. E. Colucci, and P. J. Van Soest. 1980. Investigation of chromium, cerium, and cobalt as markers in digesta. Rate of passage studies. J. Sci. Food Agric. 31:625-631.

Van Soest, P. J., J. B. Robertson, and B. A. Lewis. 1991. Symposium: Carbohydrate methodology, metabolism and nutritional implications in dairy cattle. J. Dairy Sci. 74:3583-3597.

White, T. W., and W. L. Reynolds. 1969. Various sources and levels of roughage in steer rations. J. Anim. Sci. 28:705-710.

Whittet, K. M., T. J. Klopfenstein, G. E. Erickson, T. W. Loy, and R. A. McDonald. 2004. Effect of age, pregnancy, and diet on urinary creatinine excretion in heifers and cows. Nebr. Beef Cattle Rep. MP 80A:100-102.

Williams, C. H., D. J. David, and O. Iismaa. 1962. The determination of chromic oxide in faeces samples by atomic absorption spectrophotometry. J. Agric. Sci. Camb. 59:381-385.

Zinn, R. A. 1986. Influence of forage level on response of feedlot steers to salinomycin supplementation. J. Anim. Sci. 63:2005-2012.

Zinn, R. A. 1990. Influence of steaming time on site of digestion of flaked corn in steers. J. Anim. Sci. 68:776-781.

Zinn, R. A. 1991. Comparative feeding value of steam-flaked corn and sorghum in finishing diets supplemented with or without sodium bicarbonate. J. Anim. Sci. 69:905-916.

Zinn, R. A., and J. L. Borques. 1993. Influence of sodium bicarbonate and monensin on utilization of a fat-supplemented, highenergy growing-finishing diet by feedlot steers. J. Anim. Sci. 71:18-25.

Zinn, R. A., and F. N. Owens. 1986. A rapid procedure for purine measurement and its use for estimating net ruminal protein synthesis. Can. J. Anim. Sci. 66:157-166.

Zinn, R. A., A. Plascencia, and R. Barajas. 1994. Interaction of forage level and monensin in diets for feedlot cattle on growth performance and digestive function. J. Anim. Sci. 72:2209-2215. 